Universidad de Lima

Facultad de Comunicación

Carrera de Comunicación

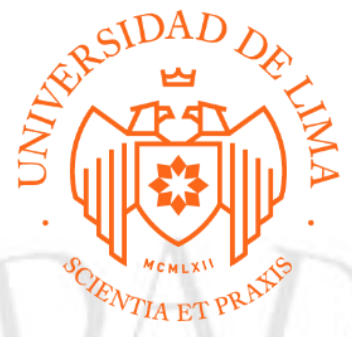

\title{
LANZAMIENTO CHICHA ANDINA
}

Trabajo de Suficiencia Profesional para optar el Título Profesional de Licenciado en Comunicación

\section{Gabriela María Calderón Sueyras y Nicole Martin Cesa}

Código 20120245 - 20122866

Lima - Perú

Mayo del 2019 


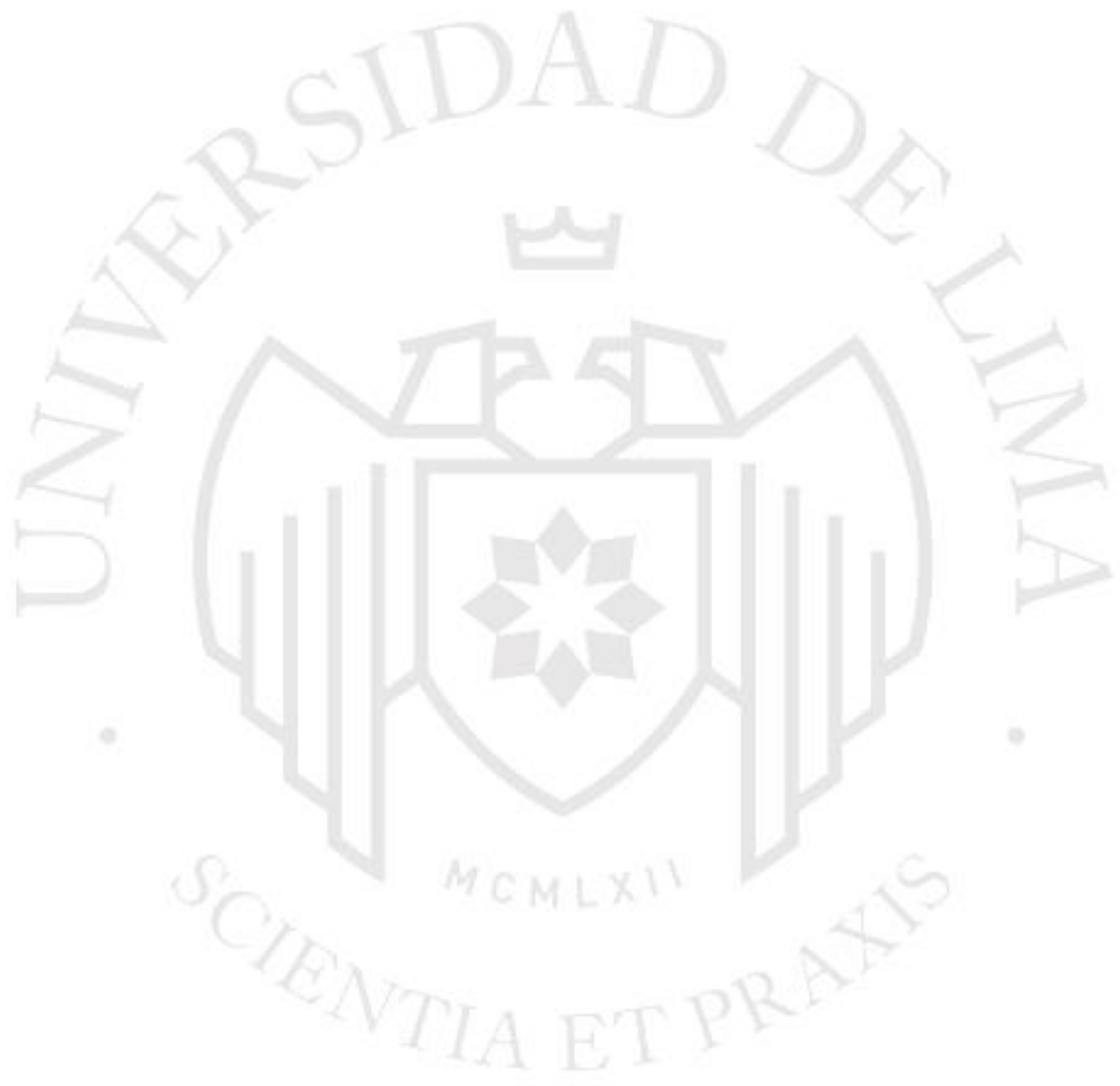




\section{LANZAMIENTO CHICHA ANDINA}




\section{ÍNDICE}

RESUMEN

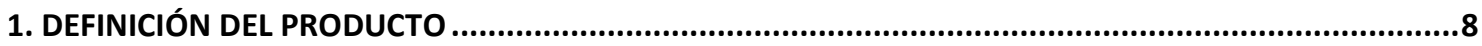

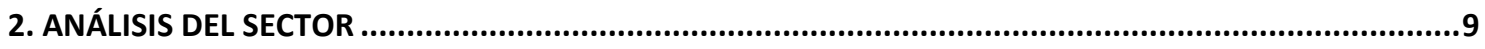

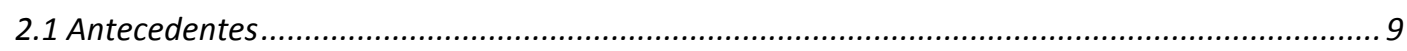

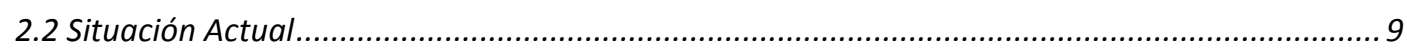

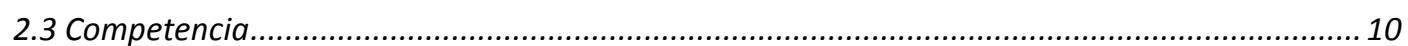

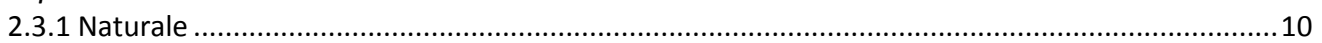

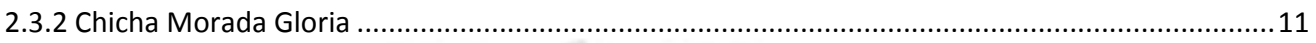

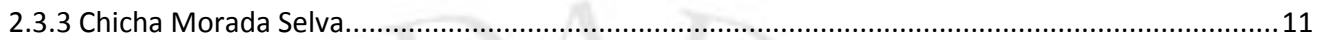

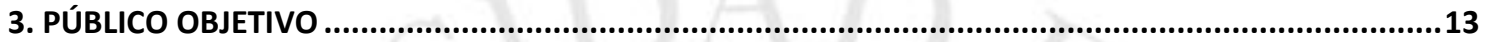

3.1 Descripción del público objetivo ................................................................................. 13

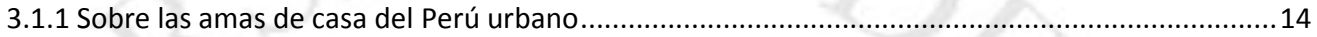

3.1.2 Sobre sus hábitos de entretenimiento y consumo ................................................................ 15

3.1.3 Sobre los medios tradicionales que consumen ...................................................................... 17

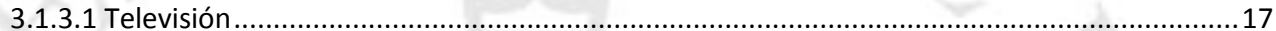

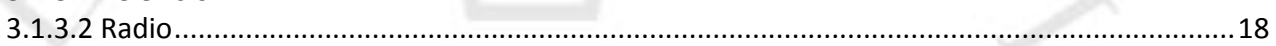

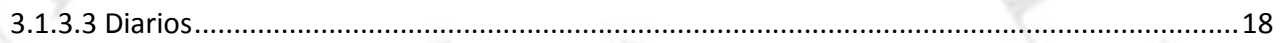

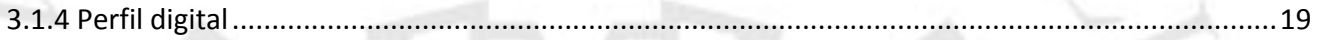

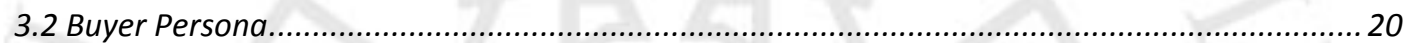

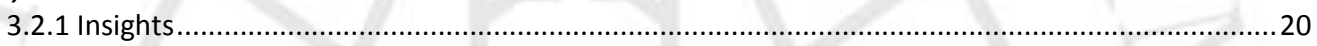

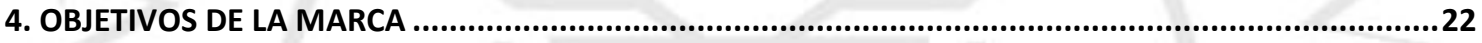

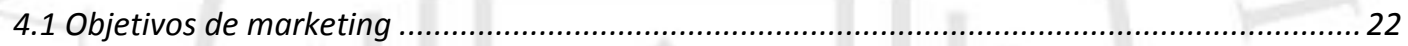

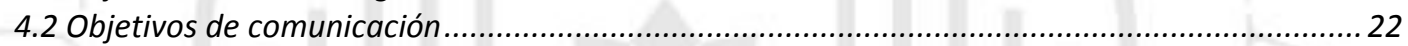

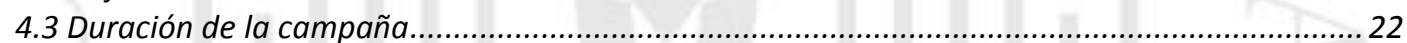

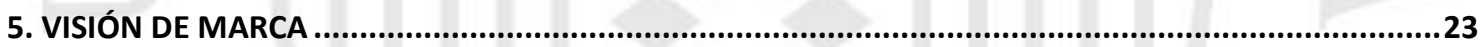

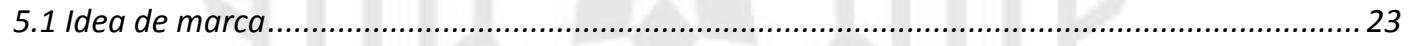

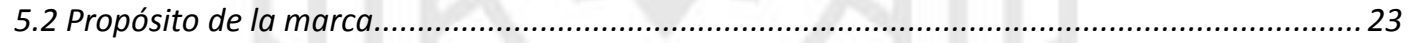

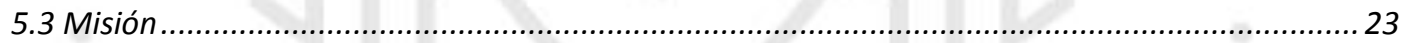

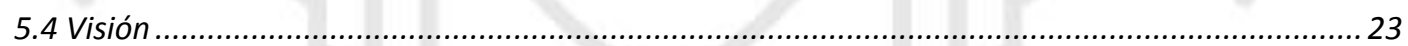

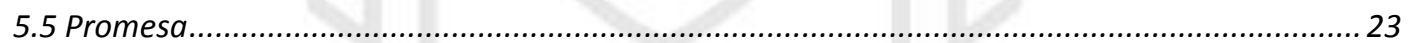

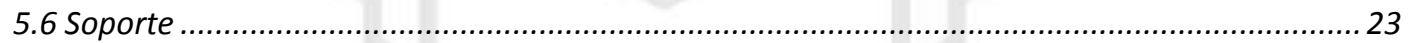

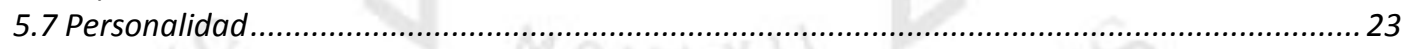

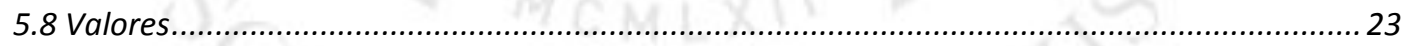

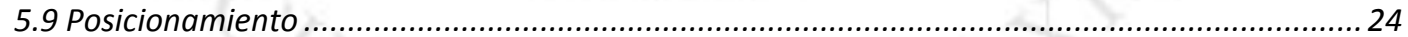

CHICHA ANDINA, ES LA BEBIDA NACIONAL 100\% NATURAL HECHA CON LA AUTÉNTICA RECETA

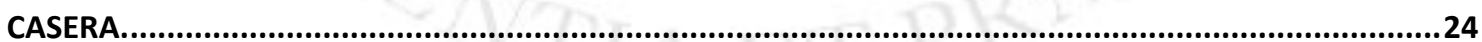

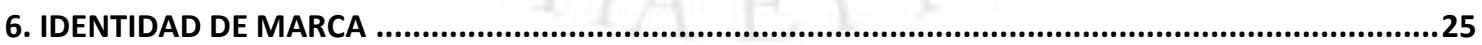

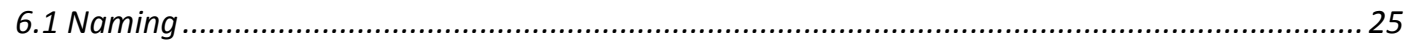

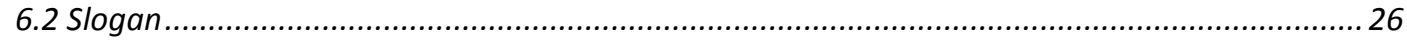

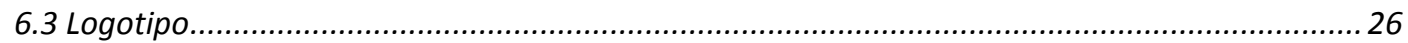

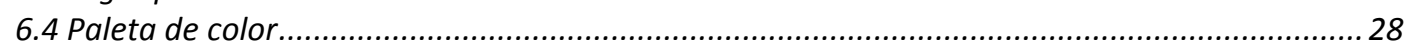

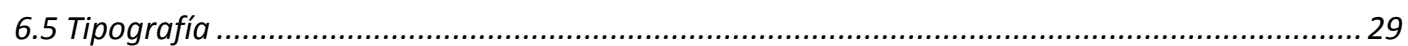

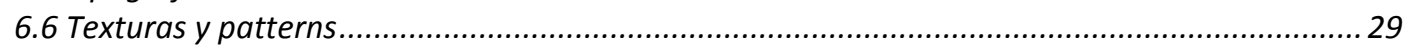

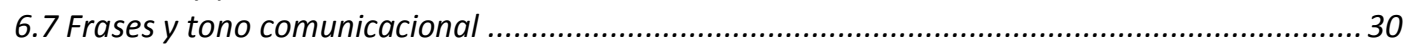

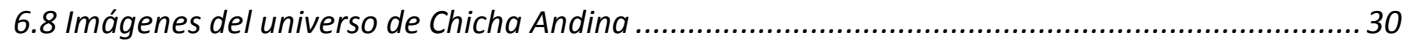

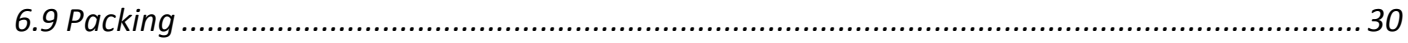

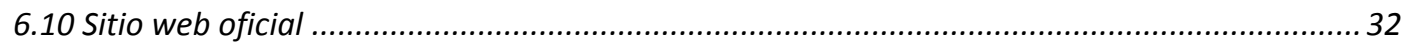

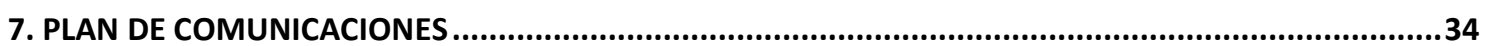




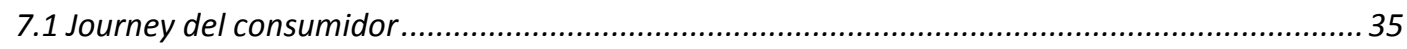

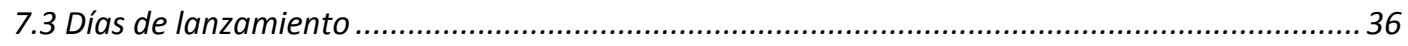

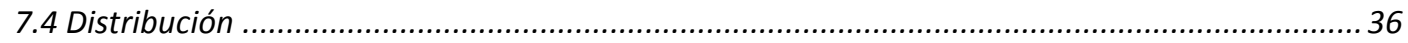

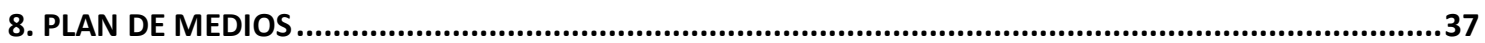

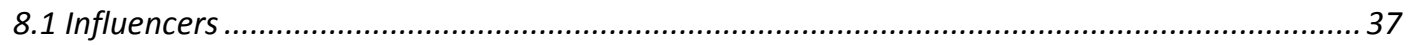

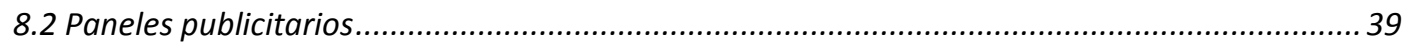

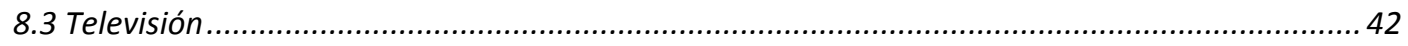

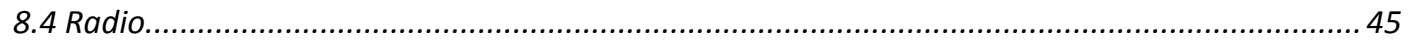

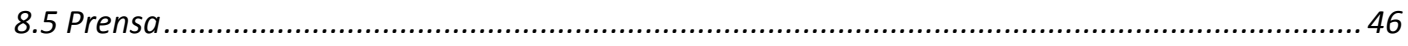

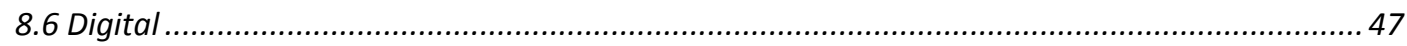

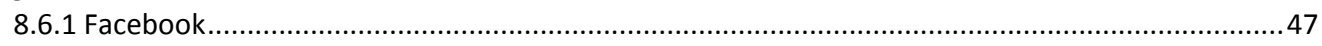

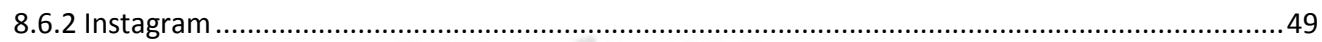

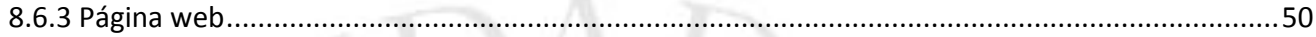

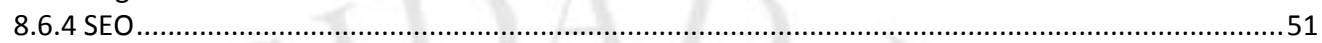

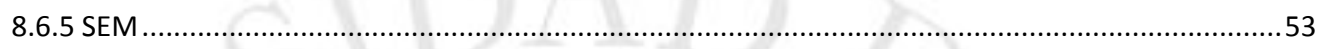

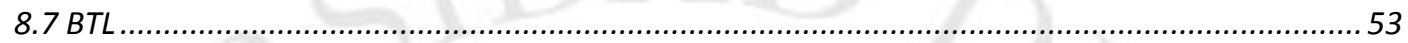

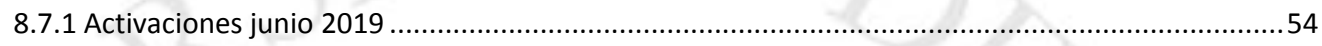

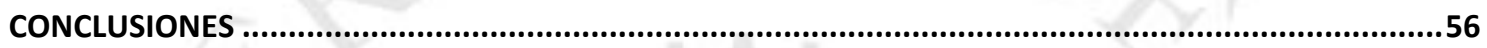

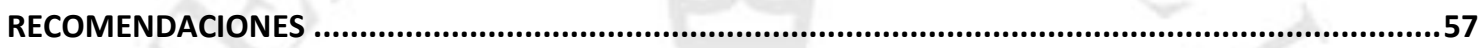

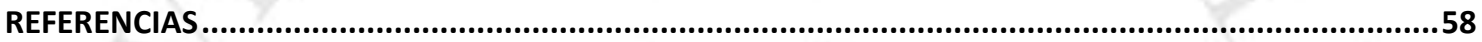

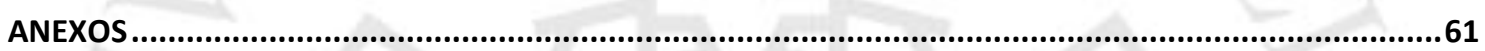

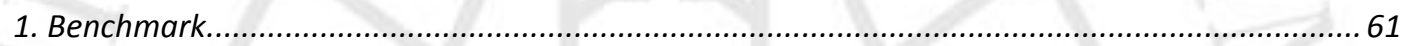

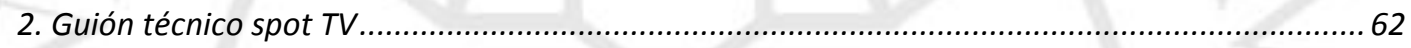

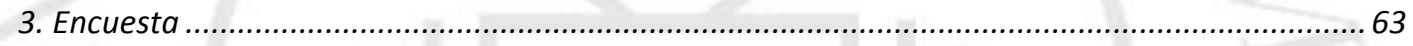

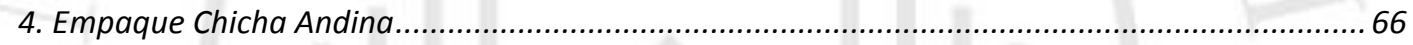

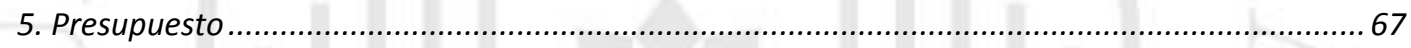




\section{RESUMEN}

La marca peruana Chicha Andina, concentrado de chicha morada $100 \%$ natural, presenta su campaña de lanzamiento para ingresar al mercado peruano. Para ello se realizó una investigación del mercado y del público objetivo. El desarrollo de la propuesta consta de la idea estratégica de la marca, el diseño de la identidad visual y la realización de la campaña de comunicación integral. Esta última proporciona una sinergia de medios para cumplir con los objetivos comunicacionales planteados. La combinación de todas estas acciones garantiza el éxito del producto y la marca en el mercado. 


\section{INTRODUCCIÓN}

El presente trabajo mostrará la propuesta de lanzamiento en el mercado peruano de la marca Chicha Andina. Su objetivo es dar a conocer y posicionar la marca en la mente de los consumidores. Esta campaña de lanzamiento busca destacar los beneficios y la propuesta de valor de una chicha morada local totalmente natural, sin azúcar ni preservantes, la cual se caracteriza por su rico sabor casero. Para ello se trabajó el concepto de la marca basada en los buyer personas, el customer journey y los insights hallados, con el que se realizó la propuesta de la identidad visual: nombre y diseño de empaque. Se propuso una estrategia del plan de medios $360^{\circ}$, compuesta en una campaña de comunicación integral para el lanzamiento de la marca en medios tradicionales y digitales. Finalmente, se presentó los valores a transmitir de la marca para conectar con nuestro público objetivo con el material del punto de venta y para degustaciones. 


\section{DEFINICIÓN DEL PRODUCTO}

Chicha Andina es un concentrado natural de chicha morada. Este es el nuevo producto de Alicorp, la empresa de bienes de consumo masivo más grande del Perú. Chicha Andina combina como ingrediente principal el maíz morado, con membrillo, piña, limón y dos especias: clavo y canela. Tiene como principales atributos que es $100 \%$ natural y no contiene azúcar. Su presentación es en botella de vidrio por $500 \mathrm{ml}$ y tiene un costo de S/. 6.00. El concentrado debe diluirse en 2.5 litros de agua, dando origen a un delicioso refresco tradicionalmente elaborado desde los tiempos preincas hasta la actualidad en el Perú. El maíz morado se caracteriza por poseer diversos beneficios: contiene un porcentaje alto de Antocianinas, el cual emite un efecto antioxidante que ayuda a regenerar los tejidos, reduce el colesterol, induce el flujo de los vasos sanguíneos y fomenta la formación de colágeno. Además, es un gran aliado para evitar el cáncer de colon. Entre otras cualidades, el maíz morado ayuda a reducir el envejecimiento del cuerpo, ataques al corazón y a estabilizar la hipertensión de las personas que sufren de este problema.

Principalmente se busca distribuir el producto en supermercados como: Wong, Vivanda, Plaza Vea y Tottus y en tiendas físicas orgánicas como: La Sanahoria, Flora y Fauna, La Colorada, Salvia, Vacas Felices, Punto Orgánico, Mara Bio Market. Los supermercados y tiendas mencionadas anteriormente se encuentran en Lima. Además, también distribuimos nuestro producto a través de tiendas virtuales como Cambia Tu nutrición y Green Xpress.

Asimismo, se puede adquirir nuestro producto mediante aplicaciones como Glovo y Rappi, servicio a pedido de delivery que se encarga de transportar nuestro producto a la ubicación que desee mediante el app. 


\section{ANÁLISIS DEL SECTOR}

\subsection{Antecedentes}

Perú es un país que posee una gran diversidad de especies vegetales y animales gracias a los microclimas que encontramos a lo largo de toda la Nación los cuales nos derivan productos agrícolas variados, pesca, aves y ganadería. (La República, 2018)

Los orígenes de la chicha morada pertenecen a la época prehispánica, anterior a la fundación del imperio incaico. En ese entonces, la chicha se bebía para fines medicinales, luego se ingería para fines ceremoniales. (NETJOVEN, 2019)

El maíz morado es un cereal originario del Perú y México. Estas culturas precolombinas lo percibían como sagrado. El maíz morado, en épocas anteriores a la conquista y colonización española, era conocido en el Perú como oro, sara ó kulli sara. El Perú fue uno de los productores más grandes de maíz morado, ya que este elaboraba refrescos y postres. El maíz morado era bastante utilizado en la Cultura Mochica, 2,500 años atrás, pues se han encontrado diversos objetos que utilizaba esta comunidad para poder hacer el consumo del mismo. (EcuRed, 2017)

\subsection{Situación Actual}

Actualmente, en el Perú, se escucha mucho hablar del concepto de tener una vida saludable. Esta hace referencia al ejercicio constante y a una alimentación consciente. Según una encuesta realizada a 757 personas (hombres y mujeres de 18 a 70 años, de todos los NSE) el 68\% relaciona el concepto de "vida saludable" con "comer sano"; el $58 \%$ lo asocia con "hacer deporte"; y el 56\% lo vincula con "pasar tiempo en familia". Además, el $25 \%$ considera que es difícil llevar una vida saludable, ya que el costo de adquisición de estos alimentos es más caro; el 19\% piensa que es complicado mantener una vida saludable por falta de tiempo; y el $12 \%$ cree que la comida chatarra es más accesible.

Cada vez más padres se preocupan por darle a sus hijos una alimentación natural, balanceada y saludable, que los ayude a crecer fuertes y sanos, dejando atrás productos 
carentes de nutrientes, con exceso de grasa y químicos que alteran principalmente el alimento de su forma original y disminuye su valor alimenticio. (DATUM, 2017)

El 24 de febrero de este año, el diario El Comercio, realizó una nota explicando sobre el octógono de la salud, el cual se debe cumplir desde el 17 de junio del presente año. "Los octógonos de advertencia se dan en el marco de la Ley de Promoción de la Alimentación Saludable para Niños, Niñas y Adolescentes, que dispuso entre otras medidas el "uso de un sistema de etiquetado de advertencia en los alimentos procesados". Es decir, se debe notar una advertencia en el caso que los productos contengan altas sustancias de sodio, azúcar, grasas trans y saturadas. Los octógonos de advertencia son de fondo negro con letras blancas, los cuales buscan resaltar dicha información. La ley de Promoción de la alimentación Saludable para Niños, Niñas y Adolescentes se dictó en el Gobierno de Ollanta Humala (2013), pero en el mandato de Pedro Pablo Kuczynski se aprobó dicha ley siendo en junio del 2017 aprobada por la Ministra de Salud, Silvia Pessah. En el manual de advertencias publicitarias se indica que estas etiquetas deben estar en la parte frontal de los productos, ya que son de mayor visibilidad para el consumidor y puede tomar mejores decisiones de compra. (El Comercio, 2019) Las iniciativas del gobierno para combatir la obesidad han hecho que los consumidores peruanos están cada vez más alertas e interesados en mejorar su salud. Es por este motivo que los consumidores están cada vez más atentos a los productos que adquieren, como por ejemplo las bebidas naturales saludables, por lo que se puede observar tasas de crecimiento atractivas de este sector naturalista. (Euromonitor, 2019)

\section{$\underline{2.3 \text { Competencia }}$}

\subsubsection{Naturale}

Sitio web: http://www.naturale.com.pe/listo-para-tomar/

Naturale es una empresa peruana con más de 15 años de experiencia. Se caracteriza por vender bebidas embotelladas listas para tomar como chicha morada, maracuyá, agua de piña golden, manzana y emoliente, las cuales no tienen saborizantes, son bajos en azúcar y son a base de pura fruta. Naturale se distingue de las bebidas tradicionales, porque tiene el valor diferencial de no interferir con los insumos de cada uno de los jugos al no utilizar 
saborizantes. Naturale ofrece jugos en botellas de diferentes litrajes desde 300 mililitros hasta 3.8 litros.

Además, venden concentrado de estas bebidas para restaurantes en todo el Perú, los cuales buscan mayor rentabilidad en sus insumos. Estos jugos se encuentran en todos los supermercados, minimarkets, tiendas de conveniencia y orgánicas. En su página web cuenta con 6 pestañas, inicio, nosotros, productos, empresas, documentos y contacto. En su sitio web dan a conocer quiénes son como marca, su historia, la misión, visión y valores de la empresa, las presentaciones de sus productos y las diferentes opciones de productos que ofrecen para empresas que son del rubro de restaurantes. En la sección de contacto se puede llenar un formulario distinto según si el interesado es una empresa, consumidor final o si es una persona que desea trabajar con ellos.

Cuenta con redes sociales, Facebook e Instagram:

- En Facebook cuenta con 148 mil seguidores, sus publicaciones son sobre los puntos de venta de estos jugos. Además, transmite los beneficios y enseña el empaque del producto y sus diferentes sabores de jugos.

- En Instagram no realiza muchas acciones, ya que publica de vez en cuando sobre los diferentes jugos que ofrecen en el mercado. Cuentan con 1,262 seguidores y no realizan historias para interactuar.

\subsubsection{Chicha Morada Gloria}

Gloria presenta un refresco sabor a chicha morada lista para tomar en diferentes tamaños de envase: botella de 3 litros, 1.5 litros y $500 \mathrm{ml}$. Este producto no precisa refrigeración en envase cerrado. Gloria no ha realizado acciones en redes sociales, es por eso que no cuenta con una página exclusiva de Chicha Morada Gloria en Facebook, Instagram, ni en la web. Solo han realizado una publicación en la página de Facebook oficial de Gloria Perú. No tienen fuerza en este medio.

\subsubsection{Chicha Morada Selva}

Sitio Web: http://www.pdandina.pe/productos/nectares/selva-jugos

P\&D Andina Alimentos S.A. es la empresa comercializadora de néctares de sabores de Naranja, Durazno, Piña, Mango y Chicha Morada. Se venden en presentaciones distintas como: personales, medianas, en caja y hasta de 1 litro.

Desde hace un tiempo han venido mejorado su empaque y han dejado de utilizar botellas de plástico reemplazándolas por unas de vidrio. Además de mejorar el logo y la imagen 
de presentación. La página web donde se encuentra la marca es la de la empresa P\&D Andina Alimentos S.A., la cual posee diferentes tipos de productos de consumo masivo. Asimismo, Selva tiene como plataforma propia únicamente Facebook $(63,000$ seguidores). En esta red social publica post con temáticas selváticas, muchas de las cuales hacen referencia a la protección de la fauna de la selva y del ambiente. 


\section{PÚBLICO OBJETIVO}

Las gestoras del hogar representan el 25\% de la población en el Perú y tienen el poder de decisión en el hogar. Se ha visto un cambio en las tareas de la casa, ya que estas han dejado de ser exclusivas para la mujer. Además, el concepto de ama de casa ha cambiado, la mujer ya no se dedica exclusivamente al cuidado de los hijos y quehaceres domésticos. Hoy en día, el ama de casa también considera a aquellas mujeres que trabajan fuera de su casa, que tienen o no hijos y que se preocupan por desarrollarse profesionalmente. El $71 \%$ de las amas de casa quieren estudiar a futuro y el $48 \%$ no trabajan y se dedican exclusivamente al cuidado del hogar. Otra inclinación de las mujeres es la búsqueda de la independencia económica. La mitad de ellas genera ingresos laborando. Mientras que las que se dedican únicamente al hogar les gustaría poseer un empleo remunerado. (Revista ANDA, 2018)

Es por eso, que la mujer peruana de hoy está enfocada en ella, en querer viajar, poner un negocio propio, estudiar y estar actualizada en todo lo que tenga que ver con su carrera para sobresalir en su trabajo. Por eso, el deseo principal de las mujeres de hoy es crecer, realizarse profesionalmente. Durante los próximos dos años, es importante saber que dentro de sus expectativas de vida no mencionan el tema de casarse y tener hijos.

La entrevistadas más jóvenes, de 18 a 34 años, tienen muy claro que lo más importante es culminar sus estudios, comprar una casa y tener un trabajo estable. Mientras que las adultas, de 35 a 54 años, tienen en mente crear su propio negocio, viajar mucho y que sus hijos tengan una carrera profesional. Y las mayores, de 55 años a más, quieren salir de su zona de comfort, irse de viaje con frecuencia y tener una casa más grande y remodelada. (DATUM, 2018)

\subsection{Descripción del público objetivo}

Nuestro target es amas de casa de NSE A, B y C. Son mujeres modernas y prácticas. Les preocupa verse y sentirse bien, y son conscientes de la importancia de comer sano. Además, relacionan lo natural con saludable y lo toman en consideración a la hora de alimentar a sus hijos. Por eso optan por alimentos que estén relacionados a tener una mejor calidad de vida y buscan marcas que cumplan con sus expectativas para satisfacer sus necesidades, intereses saludables y la de su familia. (Euromonitor,2017) 
Según nuestras encuestas a 120 amas de casa, valoran mucho el sabor real y natural de la chicha morada (hecha en casa), sin embargo, la mayoría no tienen tiempo de prepararla y piensan que prepararla conlleva un procedimiento "tedioso".

Muchas amas de casa no saben todos los valores nutritivos de la chicha, pero optan en darles a sus hijos un producto que sea natural en comparación con la artificial que viene en polvo.

\subsubsection{Sobre las amas de casa del Perú urbano}

Según Arellano, clasifica Sofisticada a mujeres de nivel socioeconómico A, B y C que tienen un mayor ingreso económico, cuentan con una buena educación y les apasiona viajar. Se preocupan mucho por las apariencias y por el consumo de productos light dentro de su familia. Al momento de comprar, tienden a inclinarse por los productos más innovadores del mercado y a la compra por internet. Cuentan con una gran afinidad por las marcas que ofrecen productos con altos valores nutricionales. (Arellano, 2017)

Siguiendo con Rolando Arellano, dentro de los seis estilos de vida que propuso en el 2017, se encuentra el denominado Modernas, donde se encuentran las mujeres de nivel socioeconómico C, las cuales son muy trabajadoras y buscan su realización tanto personal como de madres. Les preocupa mucho su imagen, por eso están a la vanguardia de las últimas tendencias en moda para verse bien. Les importa mucho su salud y la de su familia. Se preocupan por los productos que consumen, de los cuales la calidad es el factor principal, además les gusta los productos que les faciliten las tareas del hogar para reducir el tiempo y esfuerzo dentro de las labores domésticos. Asimismo, les interesa que el precio sea adecuado y asequible. Finalmente, les gusta ser visibles ante la sociedad y dar una imagen de mujeres que logran lo que se proponen. (Arellano, 2017)

En marzo del 2016, El diario El Comercio llama "mujeres maravilla" a todas aquellas que emplean su tiempo entre el trabajo, su desarrollo personal y el hogar. Es por ello, que la mujer moderna ahora tiene otras necesidades y se inclina por buscar practicidad y calidad. Las mujeres siguen siendo la mayoría de quienes realizan las compras. Adquieren productos que simplifiquen las tareas del hogar con practicidad y calidad. Además, optan por productos que sean beneficiosos para ellas, por ello se habla de una tendencia llamada wellness, buscando equilibrio en todos los niveles (emocional, físico y mental) para un mayor bienestar y para poder cumplir de la mejor manera con todas sus 
actividades. Giuliana Reyna, Gerenta general de Global Research Marketing (GRM), sostiene que las mujeres necesitan que los productos que consumen sean de calidad al igual que con el servicio que brindan, porque lo que ellas compran son experiencias, gastando un poco más por productos que cumpla sus expectativas.

Por este motivo, las consumidoras de hoy en día relacionan calidad-precio, gastando una cantidad mayor por productos que sean considerados "light" o que esté listo para servir inmediatamente. Lo que si no están de acuerdo en pagar precios tan elevados por estos.

(El Comercio, 2016)

\subsubsection{Sobre sus hábitos de entretenimiento y consumo}

- Las amas de casa dedican su tiempo libre a sus hijos, a ver televisión y a realizar los quehaceres del hogar. Asimismo, les gusta ejercitarse, escuchar música, informarse en internet y navegar por sus redes sociales. El estudio indica que el $57 \%$ de las amas de casa tienen un perfil digital, en otras palabras, se conectan al menos un día a la semana a internet. Además, el $45 \%$ cuenta con una red social, donde la favorita es Facebook. El 44\% posee un smartphone y el $42 \%$ usa el app de WhatsApp. (Ipsos, 2018)

- Los dispositivos electrónicos que utilizan son los siguientes: $71 \%$ cuenta con TV tradicional; el 26\%, un Smart TV; el 29\%, una PC; el 25\%, una laptop; y, finalmente, el 15\% posee una Tablet. (Ipsos, 2018)

- Según una encuesta a 1,000 amas de casa de todos los niveles socioeconómicos de las 11 principales ciudades del Perú Urbano, Tottus es considerado como el mejor supermercado, Saga Falabella es percibida como la tienda por departamentos más deseable. En cuanto a minimarkets, prefieren Tambo y Mimarket. El comercio de construcción, ferretería y mejoramiento del hogar preferido por las amas de casa es Sodimac e Inkafarma es la farmacia por la que más se inclinan. (Ipsos, 2018)

- Casi todas suelen aprovechar ofertas y comparar productos y precios antes de adquirirlos. Cuatro de cinco amas de casa les agrada probar productos novedosos. (Ipsos, 2018)

- La cuarta parte de las amas de casa peruanas le preocupa la cantidad y variedad de alimentos que consume, ya que se inclinan por productos saludables que les ayude a adelgazar. (Ipsos, 2018) 
- El 2x1 representa una motivación de compra, ya que es una de las promociones más atractivas para las amas de casa. A este le sigue los vales de compra con $32 \%$, los cierrapuertas con $28 \%$, descuentos con $24 \%$ y descuentos por puntos como Bonus con 24\%. (Ipsos, 2018)

- El nivel de adquisición de productos o servicios vía internet en las amas de casa es bajo, en promedio alcanza el $8 \%$. Las compras online son mayormente libros, artículos de tiendas por departamento, cupones de descuento, entre otras. (Andina, 2014)

- Según una encuesta realizada por Kantar Worldpanel al $41 \%$ de las amas de casa les parece importante poseer productos prácticos para cocinar. Cuando seleccionan un artículo se basan en la optimización de su tiempo y en ser más eficiente en sus actividades para que resulten entretenidas y no tan tediosas. (El Comercio, 2018)

- Las amas de casa en la actualidad optan por una oferta más saludable como bebidas y alimentos que a pesar de que tengan un costo mayor le aseguren bienestar y salud. (Diario Correo, 2018)

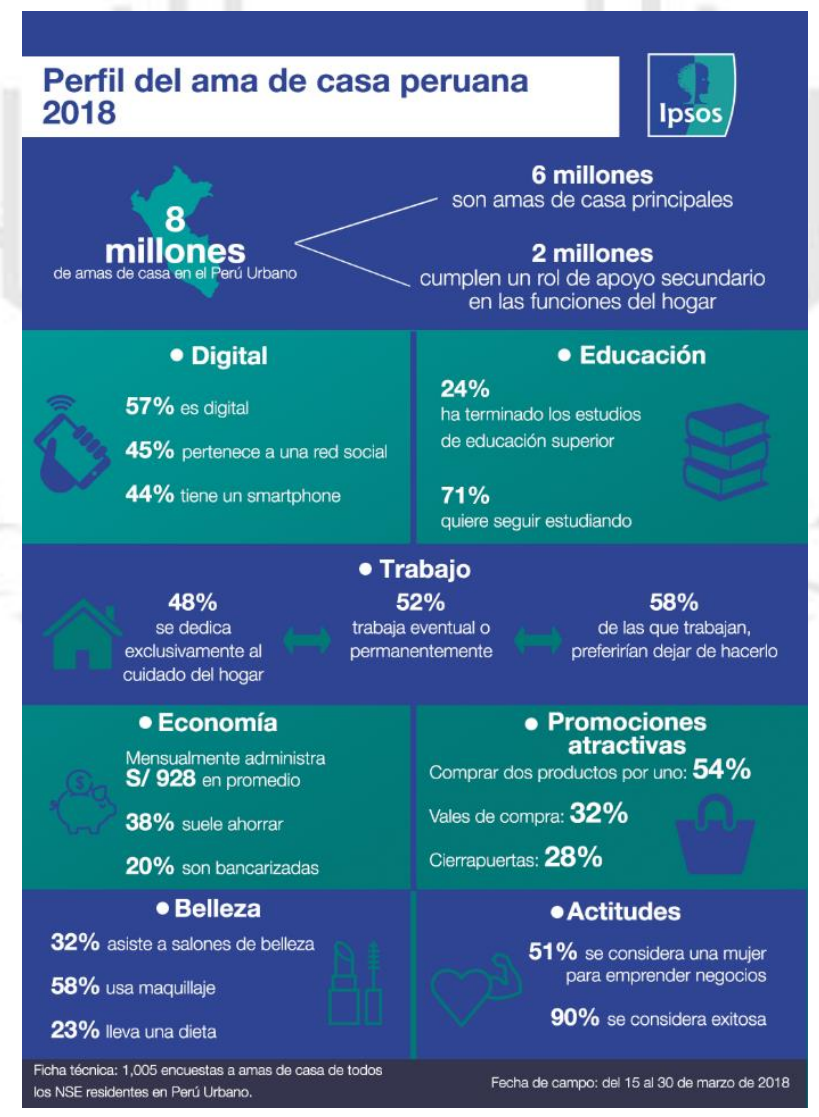

Ipsos (2018) 


\subsubsection{Sobre los medios tradicionales que consumen}

Existe una gran desconfianza por las compras por internet, ya que las amas de casa sienten que es riesgoso colocar sus tarjetas de crédito o débito en una plataforma online por tema de estafa. Además, muchas desconocen cómo funciona el sistema de las compras en internet. La mayor parte de las amas de casa se entera de los descuentos y ofertas a través de la televisión y radio, estos medios suelen influir más en su decisión de compra. (Andina, 2014)

Para realizar un mix efectivo que impacte e interactúe positivamente con el segmento objetivo es muy importante conocer las tendencias en consumo de los medios. El uso de los dispositivos digitales está en crecimiento al igual que las confluencias que generan con los medios ATL. Los hábitos de consumo de nuestro público objetivo están en constante cambio, las tecnologías son las causantes en la generación de nuevas tendencias y hábitos. (Ipsos, 2015)

\subsubsection{Televisión}

La televisión es el medio masivo más utilizado por las amas de casa para enterarse de promociones y ofertas. Este cuenta con 93\% de liderazgo, los programas de entretenimiento y noticias de canales de señal abierta son cada vez más consumidos. La televisión es el medio que influye al momento de decidir comprar un producto o servicio. Sigue siendo un medio masivo de gran influencia en nuestros días. (El Comercio, 2014) Hoy en día la publicidad en la televisión se está viendo afectada, ya que esta muchas veces es intrusiva e irrumpe la programación de los televidentes. Por eso, las pausas publicitarias son muchas veces los momentos en los que el público se conecta a otros dispositivos o cambien de programación para evitar los spots publicitarios (zapping) que no les interesa ver. Sin embargo, la televisión es uno de los medios más importantes, ya que es el que tiene un mayor nivel de penetración. La creatividad de la campaña es responsable de su efectividad. Además, realizar campañas transmedia puede mejorar el alcance de la campaña. (Ipsos, 2015) 


\subsubsection{Radio}

Edmundo Dediós, director de Mercadeo de CRP expone que la radio es un medio que ofrece cercanía, la cual además de ofrecer música brinda compañía, un locutor que entretiene y divierte la oyente. "El oyente acepta y se siente cómodo con la publicidad que escucha en la radio, pues entiende que es parte del medio de la emisora, género que escucha”. (Gestión, 2019) Tan solo el 15\% de personas varían de emisora cuando comienzan los comerciales. (Gestión, 2017) La radio se caracteriza por ser un medio tradicional con gran cobertura y de uso ocasional. (Gestión, 2018) En Lima, el 66\% es considerado radioyente habitual, en otras palabras, es una persona que escucha radio por lo menos una vez a la semana. (Ipsos, 2016) En promedio los limeños escuchan radio cinco días a la semana. Ipsos (2017) En cuanto a la publicidad digital radial, esta ha mostrado un crecimiento. El $44 \%$ de los ciudadanos de Lima escuchan radio desde sus smartphones o celulares, por lo que las marcas hoy en día optan por invertir tanto en canales offline como online. (Gestión, 2018)

\subsubsection{Diarios}

Los diarios se leen de dos maneras: por medio impreso y online. Según Eco Media, los peruanos leen diarios siendo un 50\% que los leen impreso y el otro $33 \%$ online por las aplicaciones de estos. (ECO Media, 2015)

Los fines de semana es cuando se lee más periódico, además que los días de semana por las mañanas. El día central de leer detenidamente los periódicos son los domingos. (ECO Media, 2016)

Según el estudio realizado a 500 personas, entre hombres y mujeres, que leen con frecuencia los diarios, el $91 \%$ leen los anuncios y el 11\% los recortan. Afirmando el $93 \%$ que los avisos en el diario contribuyen a la decisión de adquirir un producto o servicio. Para los Niveles Socioeconómicos A y B, El Comercio es el mejor diario del Perú. 
El hogar es lugar donde las mujeres prefieren leer los diarios, teniendo más del $60 \%$ de aprobación, seguido la oficina que es un grupo reducido que bordea el 15\%. (Ipsos, 2012)

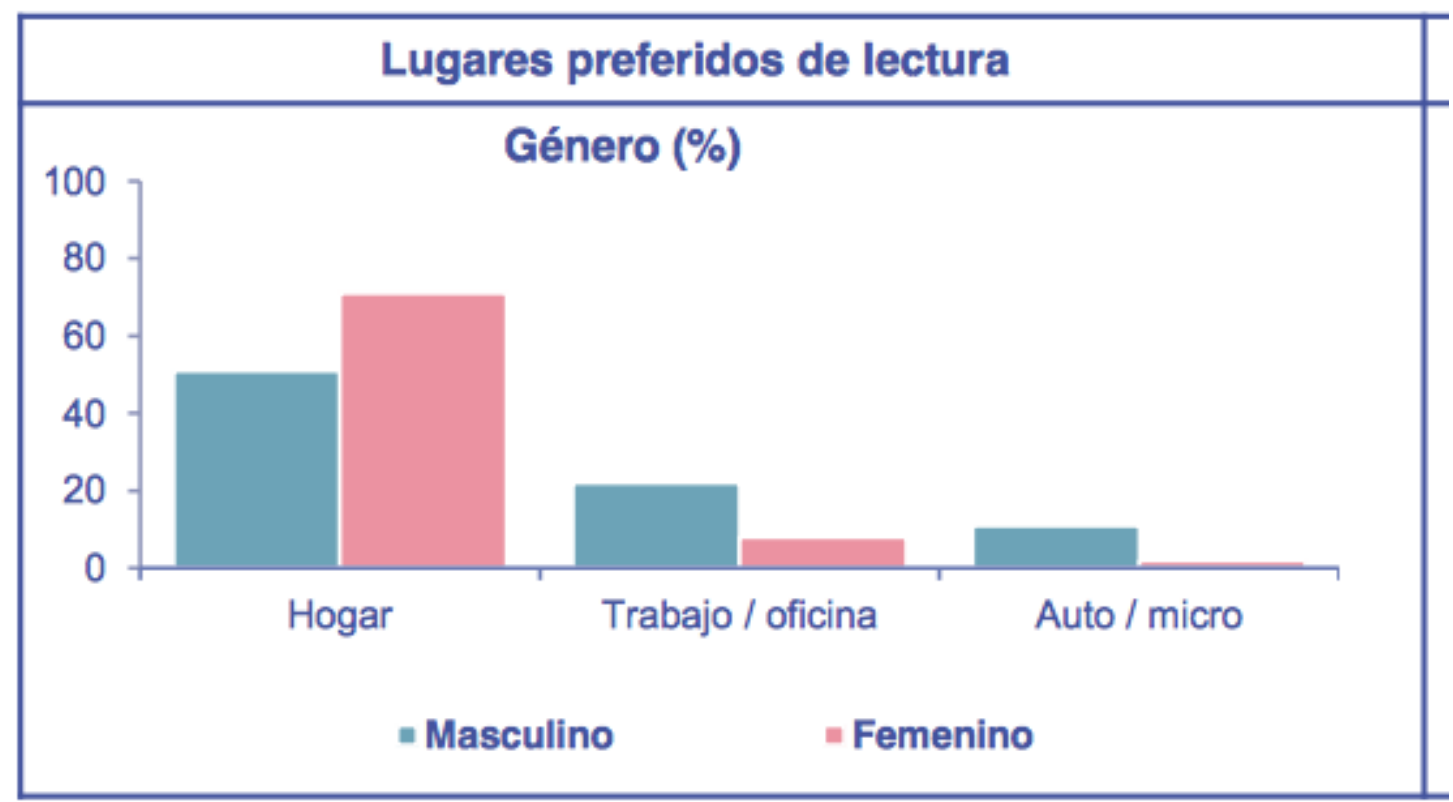

\subsubsection{Perfil digital}

Las amas de casa de hoy en día son más fieles a marcas que compran con mucha frecuencia, les gusta buscar y comparar precios para tomar una decisión. Les agrada hacerlo porque disfrutan pasar tiempo en el supermercado comparando y viendo lo mejor para su familia, por eso les gusta ir acompañadas a realizar las compras.

Realizan recomendaciones a familiares y amigos de las marcas que compran. Además, una de cada tres mujeres se considera fan de alguna marca, diciendo así que son Love Mark por cómo la recomiendan y volviéndose fieles a ellas. En cuanto a la era digital, la mitad de las amas de casa es digital y está a la vanguardia con la tecnología. Hay un $12 \%$ que son principiantes realizando compras por internet y un $26 \%$ usa un Smartphone. Con respecto a la televisión, es el medio donde se enteran de los productos y servicios. El 86\% se preocupa por su apariencia, por lo que hacen uso de cosméticos, un $2 \%$ se ha realizado alguna cirugía y $8 \%$ tiene tatuajes. Suelen estar interesadas en la moda, por eso les gusta que le regalen carteras o zapatos, ya no quieren que sean electrodomésticos. (Ipsos, 2018) A la hora de realizar compras, les gusta ver las promociones de 2x1 para animarse a comprar productos que no estaban planeados. Las mujeres de antes hubieran preferido ser maestras, doctoras o enfermeras. Mientras que ahora y en el futuro planean mudarse de vivienda, poner algún tipo de negocio de comida, de moda o abarrotes. (Revista ANDA, 2017) 


\subsection{Buyer Persona}

Luciana, mujer de 35 años, mamá de 2 hijos, casada hace 7 años con Fernando. Licenciada de la carrera de Marketing de la Universidad de Lima. Trabaja en una empresa transnacional del mejoramiento del hogar, donde se desempeña como gerenta de marketing. Sus hijos están en los primeros años de colegio. Ella se encarga que todo esté bien en la casa, cuenta con una señora, Graciela que la ayuda con los quehaceres de la casa. Luciana busca darle lo mejor a su familia, por eso está siempre buscando la mejor alimentación para todos, además de la practicidad en los productos que adquiere. Suele ir al supermercado con Graciela, su mano derecha, para realizar las compras de la semana. Luciana prepara las loncheras de sus hijos con alimentos naturales y nutritivos, ya que desea que sus hijos se desempeñen bien en el colegio, sintiéndose activos y previniendo enfermedades. Le gusta comer saludable y hacer deporte en las mañanas, ya que siente que el ejercicio la llena de energía y se libera del estrés del día a día.

Mónica, mujer de 50 años, mamá de 3 hijos, divorciada hace 15 años. Egresada de IPAE. Hace 12 años decidió formar su propia empresa de postres, los cuales los hace en su casa, para poder realizar los quehaceres de su hogar y dedicarse a sus hijos. Su marca de postres es conocida por Facebook y por el boca a boca de sus amigas y familiares. Recientemente se ha creado Instagram, el cual la está ayudando para que más personas conozcan su marca y le compren. Se encarga de realizar las compras de los ingredientes para sus postres en el mercado de Surquillo junto con Herminia, hoy su ayudante de repostería, quien antes era la nana de sus hijos. Mónica se encarga de realizar las compras del hogar una vez por semana en supermercados. Siempre busca las ofertas y los productos que sea más saludables/prácticos para ella y sus hijos. Le gusta mucho hacer manualidades como pintar, tejer y cocinar. Siempre trata de indagar e innovar en sus postres para ofrecer a sus clientes. Asimismo, le gusta pasar tiempo con sus familiares y amigos, por lo que una vez por semana almuerza con sus hijos y su madre y una vez al mes tiene pandero con sus amigas del colegio.

\subsubsection{Insights}

Realizamos una encuesta a 120 amas de casa de 28 a 55 años de nivel socioeconómico $\mathrm{A}, \mathrm{B}$ y $\mathrm{C}$ y encontramos los siguientes insights: 
¿Qué es lo primero que pasa por la mente de las encuestas cuando hablamos de chicha morada?

Perú, refresco, mamá, bebida refrescante, antioxidante, casa y maíz morado.

Este listado de conceptos fue lo que se recaudó de todo lo que escribieron en base a la pregunta escrita líneas arriba.

Asocian la chicha morada sobre todo porque es un refresco icónico del Perú, el cual es tradicionalmente bebido por la gran mayoría de familias en este país. Asimismo, conectan este refresco con sus madres y familia, ya que es una bebida que rinde para toda la familia y que combina muy bien con las comidas. Además, nos dimos cuenta de que algunas de ellas si son conscientes de los beneficios de la chicha morada para la salud y de su efecto antioxidante. Prefieren el verdadero sabor tradicional de la chicha morada hecha en casa y piensan que la preparación de la chicha morada, demanda mucho tiempo y es tediosa.

Hicimos en la encuesta una pregunta con palabras predeterminadas para que elijan cuál es la que más conexión tiene con la chicha morada y resultó lo siguiente:

Perú (64\%), hogar (22\%), compartir (6\%), cariño (5\%), festividad (3\%) y fusión (0\%). Les gusta que tenga un toque a limón y que su sabor no empalague con mucho dulzor.

Se valoraron dos insights de nuestro target: seguir disfrutando el tradicional refresco peruano: la chicha morada, el cual transmite la necesidad de pertenencia, el orgullo de ser peruano y poder disfrutar de las bondades que ofrece nuestro Perú. Asimismo, se enfatiza el beneficio del producto: su efecto antioxidante protege a nuestro cuerpo de diversas enfermedades y potencia su sistema inmunológico. 


\section{OBJETIVOS DE LA MARCA}

\subsection{Objetivos de marketing}

- Lograr una distribución del 5\% en Lima en el transcurso de los dos meses de campaña.

\subsection{Objetivos de comunicación}

- Posicionar Chicha Andina como una bebida casera premium, totalmente natural y saludable.

- Generar alto impacto y recordación de la marca Chicha Andina en el target estratégico.

- Dar a conocer los diferentes puntos de venta de Chicha Andina.

\subsection{Duración de la campaña}

La campaña de lanzamiento tendrá una duración de un mes y tres semanas. 


\section{VISIÓN DE MARCA}

\subsection{Idea de marca}

Con Chicha Andina, el auténtico concentrado casero, mantén una vida saludable.

\subsection{Propósito de la marca}

Brindar a nuestros clientes el concentrado $100 \%$ natural y casero de la bebida icónica del Perú: la chicha morada, para que vivan grandes momentos manteniendo un estilo de vida saludable.

\subsection{Misión}

Chicha Andina busca promover un estilo de vida consciente y saludable gracias a los ingredientes naturales andinos de la bebida originaria del Perú: la chicha morada.

\section{$\underline{5.4 \text { Visión }}$}

Ser un promotor de un estilo de vida saludable y consumo consciente en el Perú.

\subsection{Promesa}

Chicha Andina es un concentrado con sabor casero de maíz morado $100 \%$ natural y saludable que potencia nuestro propio mecanismo biológico con el mejor sabor y calidad.

\subsection{Soporte}

Chicha Andina es un concentrado compuesto por ingredientes andinos 100\% naturales de alta calidad los cuales son seleccionados cuidadosamente y dan como resultado el gran sabor casero de la chicha morada tradicional del Perú.

\subsection{Personalidad}

Es natural, alegre, positivo, eco-amigable, familiar, ama sus orígenes. Proyecta una buena imagen de salud y calidad. Usa un lenguaje cercano, amigable y genera credibilidad.

\section{$\underline{5.8 \text { Valores }}$}

- 100\% natural. Chicha Andina no contiene azúcar, ni químicos, es totalmente natural y contiene muchos beneficios para nuestro organismo.

- Local. Utilizamos únicamente insumos peruanos. Apoyo a los agricultores de los Andes.

- Sostenible. Botellas ecológicas y reutilizables hechas con vidrio reciclado. Cuenta con la mejor selección de insumos y hay un reconocimiento al agricultor peruano. 
- Actitud. Chicha Andina busca fomentar una alimentación consciente y saludable gracias a sus nutrientes y a su propiedad antioxidante. Frases en las chapas de la botella que motiven a sentirse bien y feliz.

- Sabor casero. Concentrado de chicha morada elaborado con la auténtica receta casera.

\section{$\underline{5.9 \text { Posicionamiento }}$}

Chicha Andina, es el concentrado de chicha morada 100\% natural hecha con la auténtica receta casera. 


\section{IDENTIDAD DE MARCA}

\section{$\underline{6.1 \text { Naming }}$}

En la encuesta que realizamos a 120 personas resultó Chicha Andina el nombre que más les agradó con una acogida del 47\% de votación, en segundo lugar, quedó Mamá Chicha con un 29\%. Los otros nombres propuestos como Sanicha, Taki, Incarú, Inca Andina y Asua tuvieron muy poca votación y no cumplieron las expectativas con nuestro público objetivo.

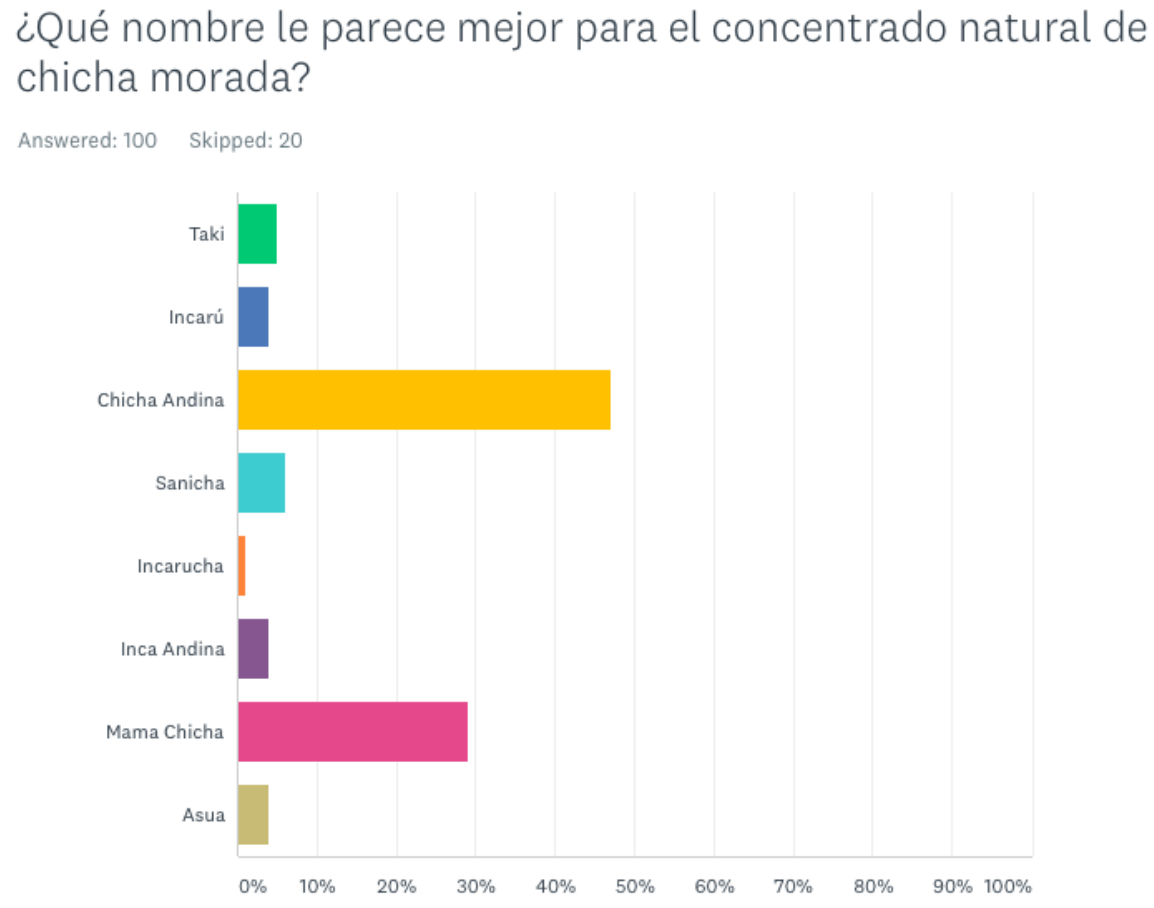

Chicha Andina valora sobre todo nuestra tierra natal, el Perú. Los Andes es la cordillera que le otorga al Perú un ecosistema muy variado y rico, por lo que le da forma a uno de los atributos más significativos del Perú: su diversidad de insumos. Es por este motivo que Chicha Andina hace alusión a lo que es el Perú, un país rico en fusiones ambientales, culturales y sociales lo cual se representa en un refresco originario rico en sabores únicos, que fusiona una variedad de ingredientes, que le dan un sentido de compartir a las familias de generación en generación. 


\subsection{Slogan}

\section{"Natural, casera y ancestral"}

Nuestro slogan se relaciona estrechamente a los insights recabados de las amas de casa, las cuales valoran mucho la receta original y natural de la chicha morada hecha en casa. Por eso buscamos posicionar nuestro producto como un concentrado de chicha morada que remite a la esencia de sabores naturales hechos en casa, con isnumos premium extraídos exclusivamente para nuestro cliente final. El cual será perfecto para compartir con toda la familia.

El concepto creativo para nuestra campaña de lanzamiento enfatiza en lo siguiente: "Con Chicha Andina, el auténtico sabor casero, mantén una alimentación sana y consciente". Por lo que se mostrará en las piezas publicitarias familias peruanas compartiendo nuestro concentrado de chicha morada con las personas que más quieren y enfatizando que su sabor es como hecho en casa.

Se mostrará en muchos medios manteniendo siempre el mismo mensaje y reforzando el slogan: "Natural, casera y ancestral", ya que nuestro fin es que Chicha Andina sea parte de las familias peruanas, que se sientan que es un producto saludable y que está hecho con la receta original de nuestros ancestros. Durante la campaña se destacarán también los atributos de sabor y los beneficios para la salud.
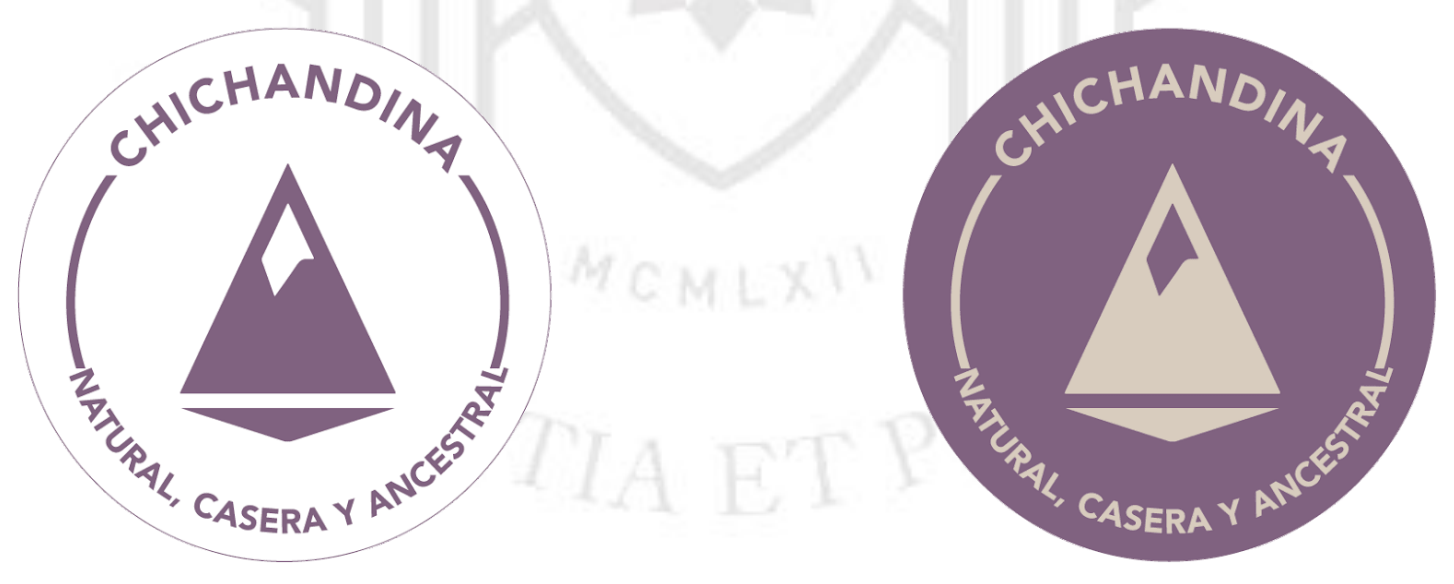

\section{$\underline{6.3 \text { Logotipo }}$}

Las letras empleadas para el logo de Chicha Andina son muy legibles y gruesas, teniendo así un mayor entendimiento de nuestro producto. Hemos trabajado en base a la letra A que se junta entre Chicha y Andina, donde se crea una montaña, que remite a los Andes. 
La hemos empleado como la insignia e icono característico de la marca, siendo parte del logo completo y del nombre. Además, se unen estas dos palabras para darle un sentido de fusión, por el hecho que la chicha es parte de los Andes y, por lo tanto, del Perú.

\section{CHICHANDINA}

\section{CHICH A NDINA}

Además, se usa la "A" en modo de variante en diferentes escenarios junto con el slogan/tagline: Natural, Casera y Ancestral.

Hemos empleado la letra A como la insignia de nuestro producto.

5.0 ICONO INSIGNIA

USO CON COLORES
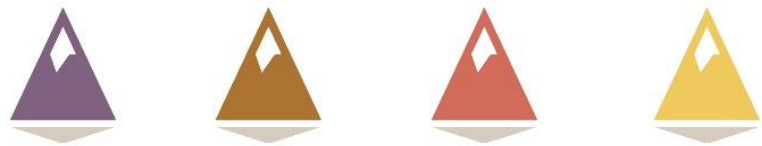

USO CON IMÁGENES
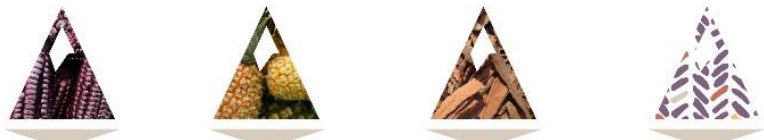

Asimismo, hemos realizado propuestas donde esta letra se puede utilizar por sí sola, de tal manera que nuestro público objetivo la identifique con Chicha Andina. Para esto la hemos diseñado en forma de nevado, en referencia a la cordillera de Los Andes. Además, se le implementarán diferentes fondos con los colores asignados en el branding de nuestra botella y según las frutas que contiene la chicha morada. Jugaremos con palabras que remitan a los beneficios de nuestro producto como casera, sabrosa, saludable, natural de la siguiente manera: 


\section{SAROSA}

\section{SA LUDABLE}

\subsection{Paleta de color}

En nuestra propuesta de color, hemos optado por colores desaturados que remitan a la madera, la vegetación, la tierra y a una conciencia ecológica. "Los cafés, intensos y cálidos, evocan a los materiales naturales y llegan emocionalmente a las personas, a través del recuerdo, la nostalgia y lo de antaño". (ADESIGN PERU, 2010) Es por este motivo que con estos colores queremos dar una sensación de tradición familiar. Además, hemos realizado una combinación con tonos rubí que transmiten vitalidad, salud y energía y son característicos del maíz morado. (ADESIGN PERU, 2010)

Los colores están ligados a la naturaleza y al color de los Andes. El color principal de la marca es el color morado, porque es el mismo que tiene nuestro producto. Luego, proponemos el uso de los colores más vivos y frescos como habano, terracota, arena y neutral que van acorde para la creación de nuestro packing. Colores que remiten a nuestros Andes generando piezas alegres, joviales, atractivas.

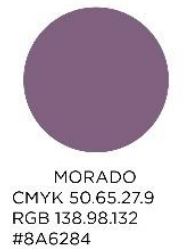

RGB 138.98 .132
\#8A6284
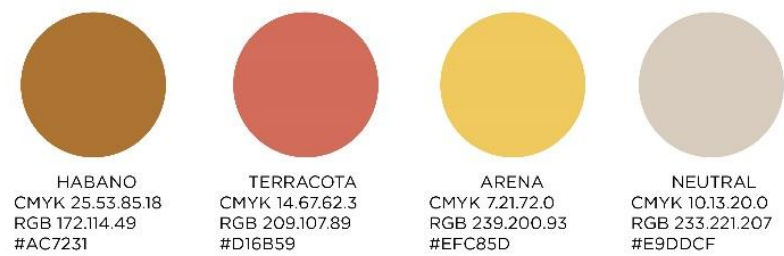


\section{$\underline{6.5 \text { Tipografía }}$}

Las tipográficas que hemos elegido son Muller y Aubrey:

- Muller ha sido implementada en nuestro logo principal, pues se muestra acorde a nuestro producto, letras fuertes, llamativas y con mucho peso. Haciendo que genere un dinamismo en nuestra presentación.

- Aubrey: tipografía delicada, femenina y legible. Se utilizará principalmente en los paneles publicitarios y piezas digitales. Además, se aplicará para las palabras que remiten a Chicha Andina: familia, saludable, natural, salud, entre otros.

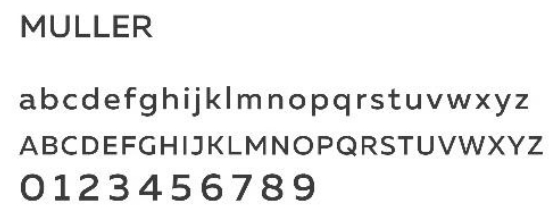

\section{Aubrey}

abcdefghijkImnopqrstuvwxyz ABCDEFGHIJKLMNOPQRSTUVWXYZ 0123456789

\subsection{Texturas y patterns}

Nuestras texturas y patterns son hechas $100 \%$ a mano, ya que nuestro fin es remitir lo natural, el cuidado de nuestro producto y la manera delicada en que se trabaja con nuestros colaboradores para llevar Chicha Andina a sus mesas.

Nuestro fin principal es mostrar las texturas en su forma más natural posible, pues queremos mostrar que sus insumos son de alta calidad y que se extraen de la mejor manera en nuestros Andes.

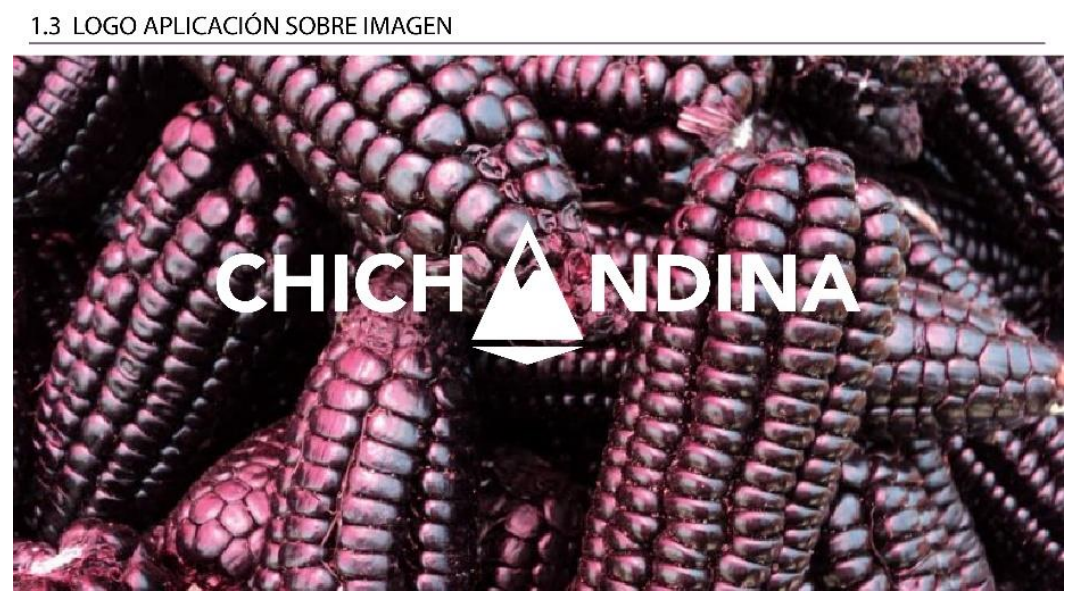




\subsection{Frases y tono comunicacional}

El tono de comunicación empleado en toda la campaña es cercano, amigable, alegre y familiar. Se expresa directamente a nuestro público objetivo, amas de casa, enfatizando en los beneficios que posee nuestro producto. Empleamos un lenguaje coloquial, directo y fácil, el cual es entendido y asimilado de manera rápida y directa.

\subsection{Imágenes del universo de Chicha Andina}

Chicha Andina se caracteriza por utilizar imágenes reales, de familias peruanas que se sientan a la mesa a compartir almuerzos con buenas conversaciones y felices de pasar tiempo juntos. Imágenes de cada uno de los insumos que se necesitan para el concentrado de chicha morada, mostrando así su textura, los colores reales de las frutas siempre bien cuidadas y detalladas. Hemos buscado que las frutas se vean de muy buena calidad, que remitan que son productos de alta calidad, seleccionados de la mejor manera y al detalle por nuestros colaboradores de los Andes que trabajan para darnos lo mejor de sus cosechas.

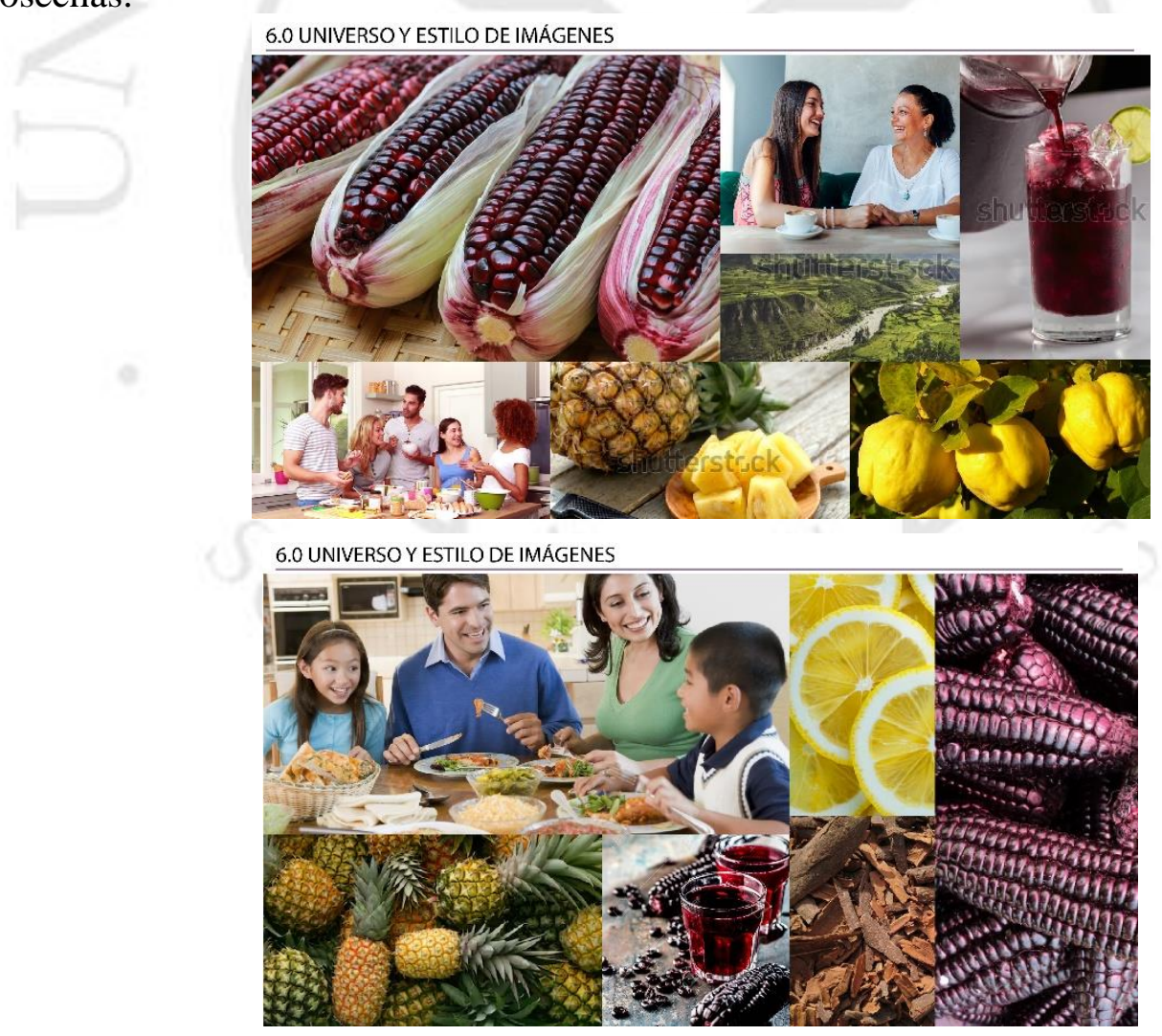

\subsection{Packing}

Nuestra botella de vidrio reciclado contiene $500 \mathrm{ml}$. Tiene como ilustración la cordillera de los Andes peruanos y animales representativos de nuestra fauna como la alpaca, mono 
y cóndor. El envase de nuestro producto es transparente, ya que el contenido de nuestro concentrado es de color morado y traspasa el color a la botella dándole su tonalidad.

En la parte frontal de la botella hemos colocado el nombre del producto y parte de la ilustración de los Andes y animales peruanos. En la parte dorsal, se encuentra el litraje de nuestro producto $(500 \mathrm{ml})$, los ingredientes, hacemos referencia a que es un producto $100 \%$ natural y que no tiene azúcar. Además, explicamos cómo debe de usarse nuestro producto los $500 \mathrm{ml}$ se vierte en 2.5 litros de agua y lo más importante que debe estar siempre refrigerado.

\subsection{PACKAGING BOTELLA}
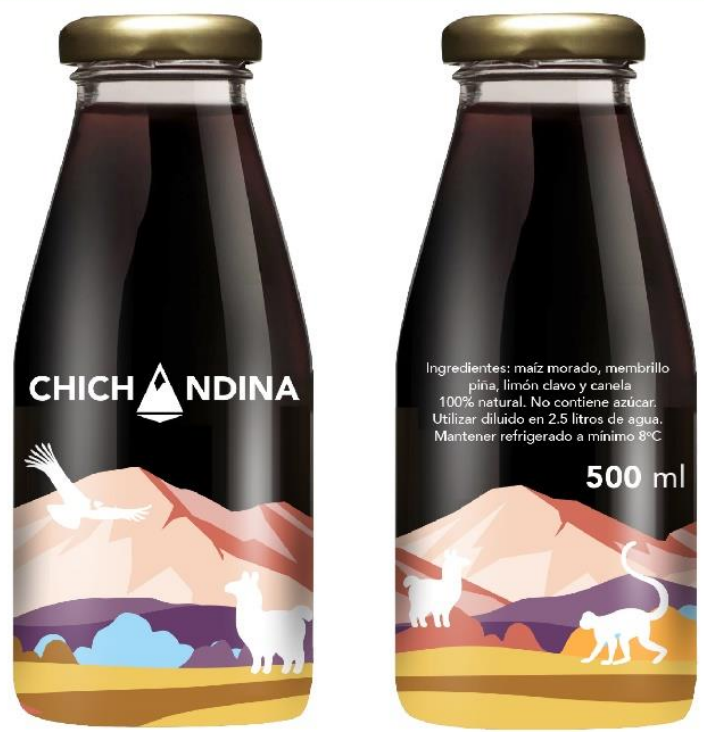

7.0 PACKAGING BOTELLA

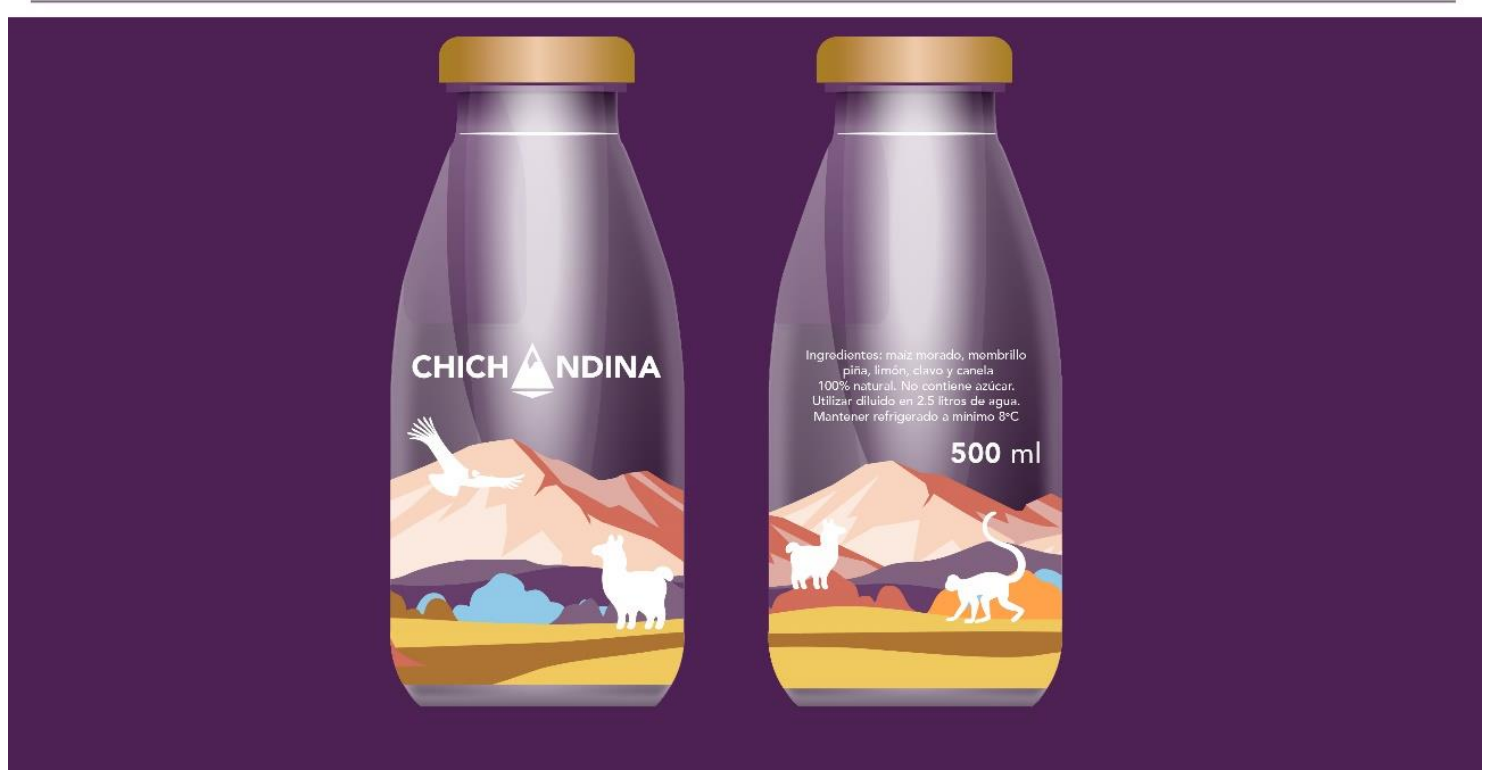


Las chapas tendrán un sticker con el logo y slogan de la marca. Optamos por colores diferentes que estén alineados a la marca: morado, habano, terracota y arena. En su interior tendrán mensajes motivadores, los cuales están enfocados en la vida saludable, en tener buenos pensamientos y ser mejor cada día.
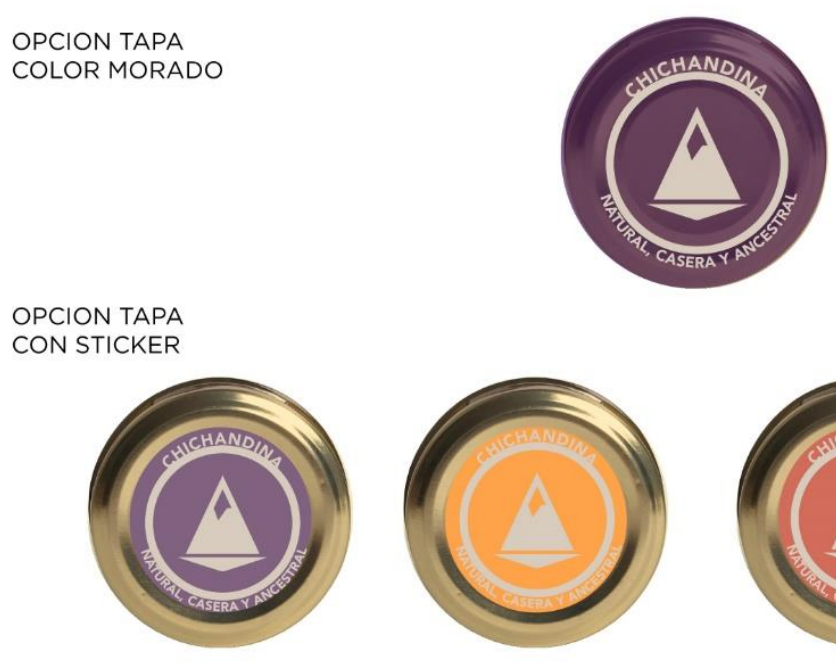

OPCION TAPA
CON STICKER
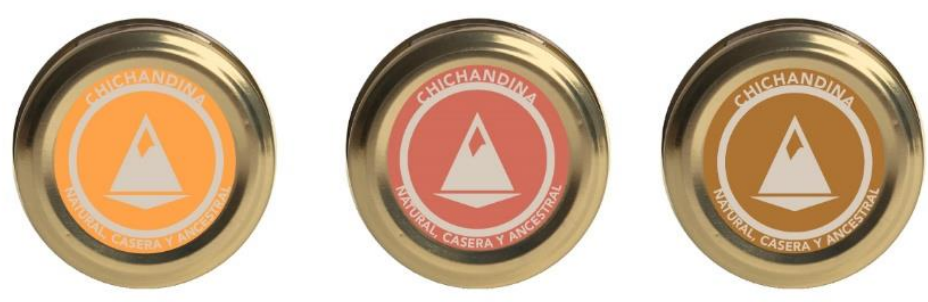

\subsection{PACKAGING BOTELLA - TAPA INTERIOR}
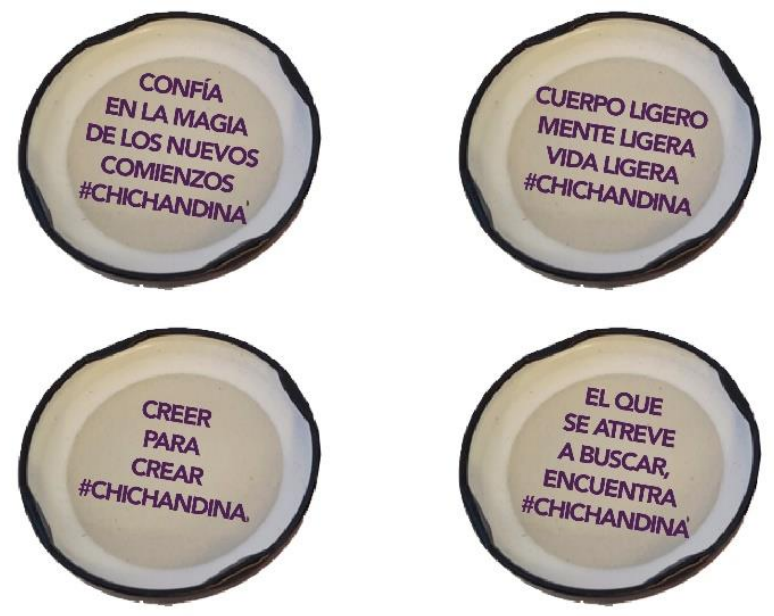

\section{$\underline{6.10 \text { Sitio web oficial }}$}

Nuestra página web contiene 5 pestañas para interactuar con nuestros usuarios: inicio, nosotros, producto, blog y contacto.

- En "Inicio" se encontrarán con una imagen bastante llamativa de Chicha Andina y a los costados las diferentes frutas que contiene nuestro producto, maíz morado, 
membrillo, piña, clavo y canela. Además, del slogan "Natural, casera y ancestral". Lo que queremos es que nuestro slogan se posicione en la mente de nuestras consumidoras.

- En "Nosotros" encontrarán toda nuestra historia, la misión, visión y valores que forman parte de nuestra empresa.

- En "Producto" enseñaremos la botella en 3D y contaremos con botones que transmitirán cómo está hecha la botella y cómo es que se produce, así como los insumos utilizados para la realización del concentrado de chicha morada. Además, el público podrá observar los beneficios que tiene Chicha Andina.

- "Blog", es una sección dentro del sitio web en donde redactaremos muchas notas de recetas de platos caseros, tips para el cuidado de medio ambiente y diferentes maneras de reciclar las botellas de Chicha Andina. Asimismo, podremos enseñar a sembrar plantas en la botella de Chicha Andina, usarla como florero, pintarlas para que decore la sala, entre otros.

- En "Contacto" se encontrarán todos nuestros puntos de venta físicos, tanto supermercados como tiendas orgánicas, todas especificadas con la dirección y referencia, además de estar integradas con Google Maps. También se contará con un espacio para promocionar las tiendas online donde se puede encontrar nuestro producto y en donde cada empresa distribuidora estará linkeada para que puedan acceder a comprar online directamente. Por último, se mencionarán las aplicaciones de delivery, Glovo y Rappi, para que puedan conseguir nuestro concentrado de chicha morada sin tener que salir de sus casas desde sus smartphones.

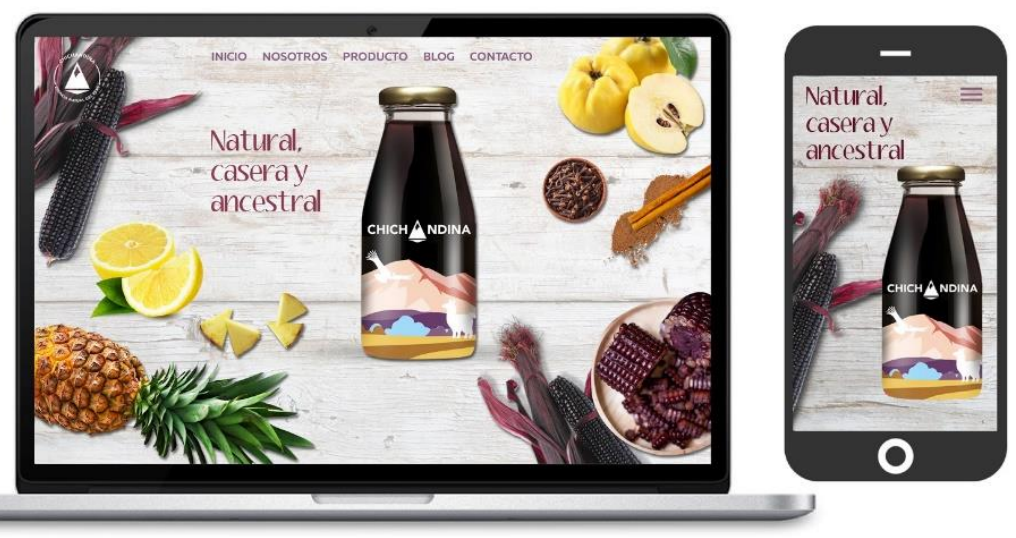




\section{PLAN DE COMUNICACIONES}

El plan de medios está estructurado en el anexo y en el documento de excel "Presupuesto de medios", en este se encontrará todos los detalles de costo de pauta, producción, calendario de publicaciones y demás.
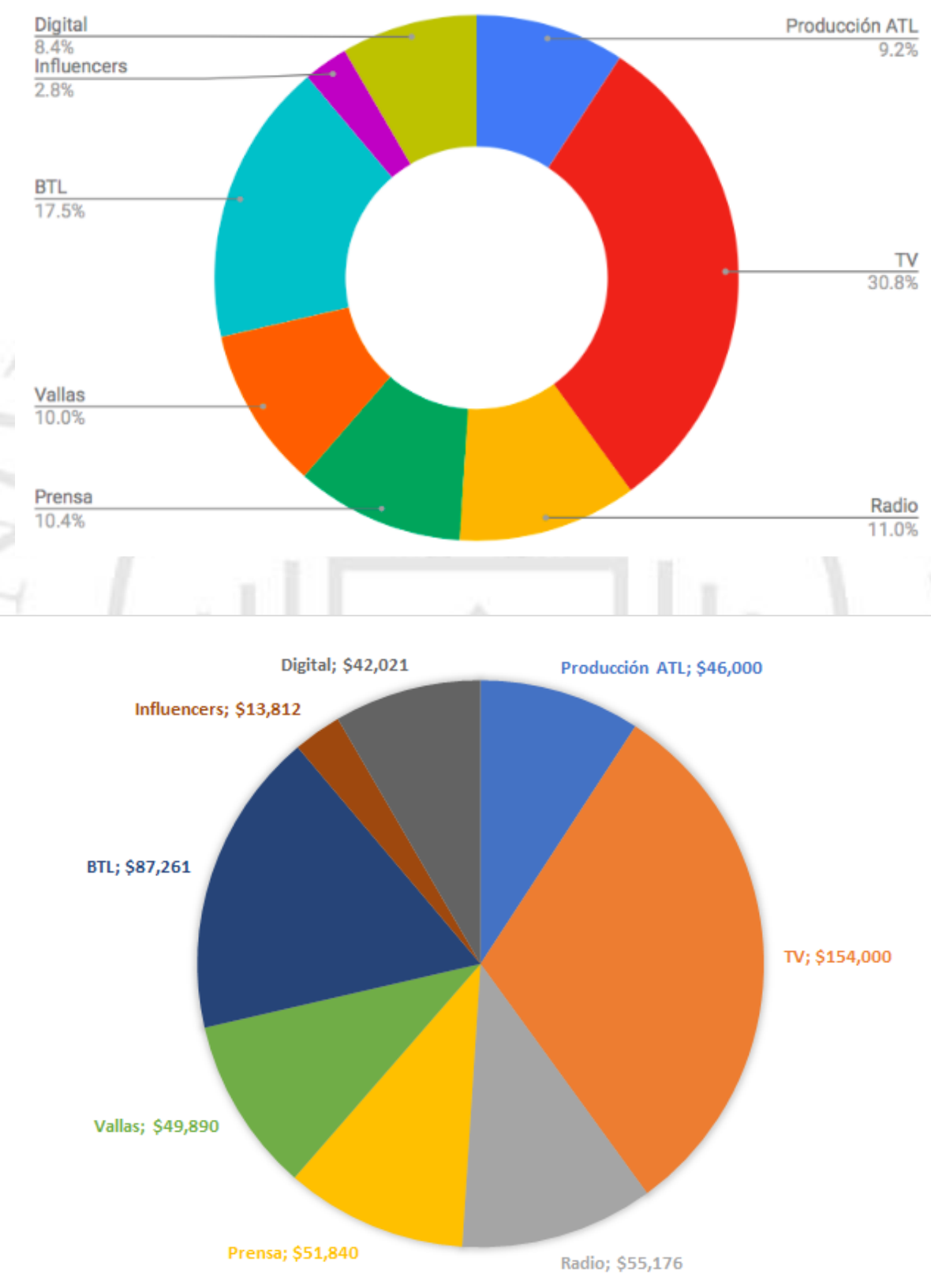
Realizar una campaña 360 es primordial, es por eso que Chicha Andina hará una campaña de dos meses, junio y julio del 2019. Tendremos impacto tanto en vía pública, televisión, radio, redes sociales, puntos de venta como con algunas influencers que cumplen con el estándar de nuestro público objetivo. La influencers fueron elegidas por la vida que llevan y la cantidad de seguidores que tienen. Ellas son Chiara Pinasco, Karen Schwarz, Ximena Llosa, Gianella Neyra y Paloma Derteano. Se eligió empezar la campaña en junio, porque es previo a fiestas patrias, en donde los peruanos nos sentimos más orgullosos y patrióticos del país en el que vivimos. Queremos que tenga una acogida muy fuerte, por eso la campaña continuará hasta el mes de julio. Se buscará posicionar Chicha Andina como la bebida nacional $100 \%$ natural hecha con la auténtica receta casera.

El tono comunicacional que vamos a emplear en toda la campaña es motivacional, ya que Chicha Andina es una esencia natural que te invita a tener un estilo de vida más saludable. Se centrará en estar presente y acompañar los almuerzos de todos los días, las comidas familiares de los fines de semana, momentos importantes. Queremos que sea un producto que apele a los sentimientos, por eso será con un tono comunicacional muy positivo, donde se mencionen los grandes beneficios que tiene nuestro producto y el sabor hecho en casa que tiene nuestro concentrado.

\subsection{Journey del consumidor}

El proceso de compra del consumidor se basa en tres etapas: reconocimiento, consideración y decisión. Es por este motivo, que debemos realizar una campaña que busque atraer, enganchar y deleitar con el consumidor, empatizando y entendiendo sus deseos y necesidades para poder establecer una relación duradera con este.

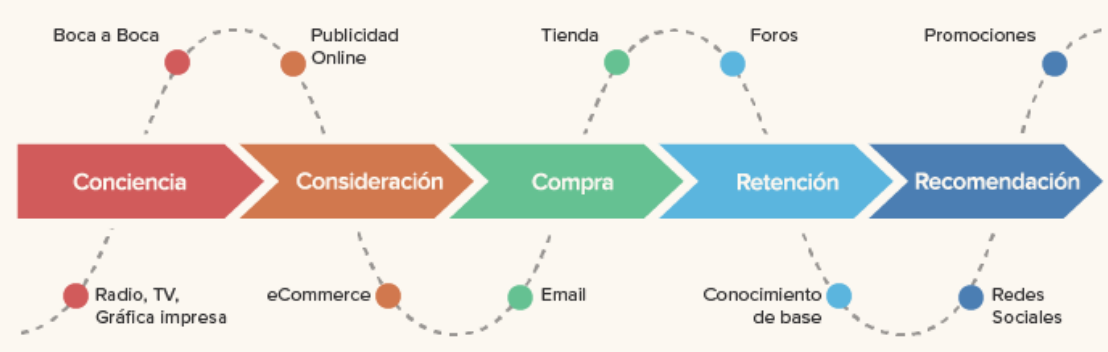

Fuente: Survey Gizmo. 


\subsection{Días de lanzamiento}

Durante la etapa de lanzamiento se utilizará publicidad ATL, BTL, en redes sociales y piezas de POP. Haremos un spot de televisión de 30" y un spot de radio de 10" y 15", vallas publicitarias, publicidad en diarios, revistas locales y diversos posts en las plataformas digitales. La publicidad está centrada en dar a conocer el producto, sus beneficios y los puntos de venta en donde lo podrán adquirir. La campaña de lanzamiento tendrá una estrategia multicanal, ya que los mensajes que emitirá Chicha Andina se adaptarán a las diversas necesidades de su audiencia.

\subsection{Distribución}

Nuestra campaña se enfocará solamente en la distribución del producto en Lima y en las principales provincias como Arequipa, Trujillo y Piura, ya que nuestro principal objetivo es penetrar en los supermercados y tiendas orgánicas locales en las principales provincias del país.

Con respecto a las tiendas orgánicas en Lima, nos enfocaremos en que el producto se deguste en La Sanahoria, Flora y Fauna, Mara Bio Market, La Colorada y Punto Orgánico. 


\section{PLAN DE MEDIOS}

\section{$\underline{8.1 \text { Influencers }}$}

Los influencers, hoy en día, son fundamentales para las estrategias de marketing digital, ya que son expertos en un tema o sector, por lo que generan confianza en sus seguidores, los cuales están dispuestos a seguir sus recomendaciones. Esto contribuye cuando los influencers hablan bien de tu marca, ya que se crea un interés en la audiencia por probar o saber más del producto.

Las influencers que hemos elegido son Chiara Pinasco, Karen Schwarz, Gianella Neyra, Ximena Llosa y Paloma Derteano, ya que tienen un estilo de vida acorde a la personalidad de la marca, además cuentan con gran cantidad de seguidores.

- Paloma Derteano solo cuenta con la red social de Instagram y posee 93.3K de seguidores. Paloma tiene 28 años y es una mujer casada desde hace un año. Es emprendedora de "Sin Envolturas" marca de regalos para novios, y "Branding Constante" empresa de branding digital. Asimismo, cuenta siempre su vida a través de instastories y posts. Le gusta hablar de su vida de casada, la cual denomina \#PasionRural, ya que su marido es agrónomo de profesión y tienen fundos de uvas en Ica. Paloma y Cristóbal (su esposo) tienen una casa en Ica, por lo que ella debe distribuir su tiempo entre pasar tiempo con él y sus negocios en Lima. Paloma juega mucho en Instagram con el tema de "ama de casa por siempre" (\#AmaDeCasaPorSiempre). Muestra siempre lo que prepara y cocina para su esposo ante cámaras. Le encanta pasar tiempo con sus perros, los cuales quiere como sus hijos. Hasta el momento no planea tener hijos los cuales denomida como "marmoleados" por el hecho que ella es morena y su marido es rubio. Ella tiene mucho contacto con mamás jóvenes, porque su manera de comunicarse es muy directa y jovial. Recomienda siempre a través de su cuenta en Instagram lo que utiliza y mantiene una comunicación cercana con sus seguidores. Además, también gran parte de su comunidad son hombres, ya que la ven como un personaje que se dirige con mucho humor, carisma y espontaneidad, realizando bromas y diferentes caracterizaciones. Paloma será nuestra primera influencer, ella mostrará el producto en la segunda semana de la campaña. Realizará una explicación de forma dinámica y divertida de cómo verter el concentrado en una jarra de agua para su consumo. 
- Karen Schwarz tiene 62K en Facebook y 2.4M seguidores en Instagram. En sus redes sociales se le percibe muy activa, ya que distribuye su tiempo entre los programas de television que conduce en Latina, las activaciones donde la contratan y su familia. Antonia, su hija de 2 años, tiene un protagonismo muy importante en sus redes sociales, porque muestra todas sus actividades diarias como sus alimentos, juegos y aprendizaje. Karen se preocupa por dar a conocer aquello que consume, ya que se basa en la calidad y precio, recomienda productos que sean accesibles y de fácil prepararación.

- Ximena Llosa tiene 62K en Facebook 57.2K seguidores en Instagram. Es chef de profesión y actualmente cuenta con un programa de cocina en Movistar Plus. En sus redes sociales siempre muestra las recetas que realiza en su día a día, así como las loncheras saludables que le prepara a sus hijos para el colegio. Las actividades diarias que desempeña son conducir el programa de tv, hacer postres y platos salados, correr por hobbie y llevar una vida feliz con su familia y amigos. Le encanta recomendar productos nuevos y que sean de calidad. Busca exponer al público marcas que sean de uso práctico y amigable con el medio ambiente.

- Chiara Pinasco, una reconocida actriz y modelo peruana, tiene 105K en Facebook y $315 \mathrm{~K}$ seguidores en Instagram. Ella lleva una vida muy intensa y agitada, ya que viaja constamente por trabajo, conduce un programa de televisión los sábados por América TV el cual se denomina TEC y trata de pasar el mayor tiempo posible en familia. Es una persona que busca ser discreta en redes sociales con respecto a su familia, por eso no muestra el rostro de su hija y muy pocas veces el de su esposo. Chiara enfatiza mucho en sus redes sociales acerca de la alimentación que le otorga a su hija, como también de diversas técnicas de estimulación temprana. Ella evita que consumir azúcar y fomenta una alimentacion saludable con productos naturales.

- Gianella Neyra tiene 543K en Facebook y $1 \mathrm{M}$ de seguidores en Instagram. Gianella es una famosa actriz y actualmente es protagonista de una obra de teatro llamada Dos Más Dos. Muestra en sus redes sociales las actividades que realiza 
en su día a día, es decir las grabaciones de la próxima pelicula a estrenar, el teatro y su familia. Trata de no enfocar a sus hijos públicamente por cuidado y seguridad. Sin embargo, siempre transmite a su comunidad lo bien que se lleva con su familia y la buena alimentación que consumen. Es una madre que se preocupa por que en su casa se alimenten de manera saludable y a la vez que la comida tenga un buen sabor.

\section{$\underline{8.2 \text { Paneles publicitarios }}$}

Hemos elegido colocar paneles publicitarios en cuatro lugares estratégicos: Cerro Centinela en La Molina, Estadio Bonilla en Miraflores y Guardia Civil en Javier Prado y a la altura del pentagonito en San Borja. Nuestras vallas publicitarias se encontrarán establecidas en los lugares mencionados los dos meses que dura la campaña de lanzamiento. Las cuatro ubicaciones son muy concurridas por nuestro público objetivo, ya que son zonas que concurren con frecuencia ya sea para ir a trabajar, llevar a sus hijos al colegio, realizar compras y más. Hemos considerado invertir en paneles publicitarios estáticos dentro de nuestro mix de medios, ya que proporcionan un gran alcance y frecuencia. Consideramos que su alto impacto y presencia permanente generarán un alto brand awareness. La ventaja de los paneles de lona frente a los digitales es que no generan contaminación visual, es decir mantienen un mensaje único y claro de manera permanente y no de manera dinámica como lo hacen las vallas digitales, en donde diversos mensajes publicitarios de distintas empresas varían cada cinco segundos aproximadamente. Los paneles estáticos potenciarán el reconocimiento de marca al poseer un espacio totalmente enfocado en el producto para darle una relevancia especial. Cada vez hay más cantidad de carros en Lima, y por lo tanto de tráfico, es por este motivo que las personas pasan muchas horas de su día transportándose de un lugar a otro, por lo que son más propensas a observar las vallas publicitarias.

Paneles junio: 

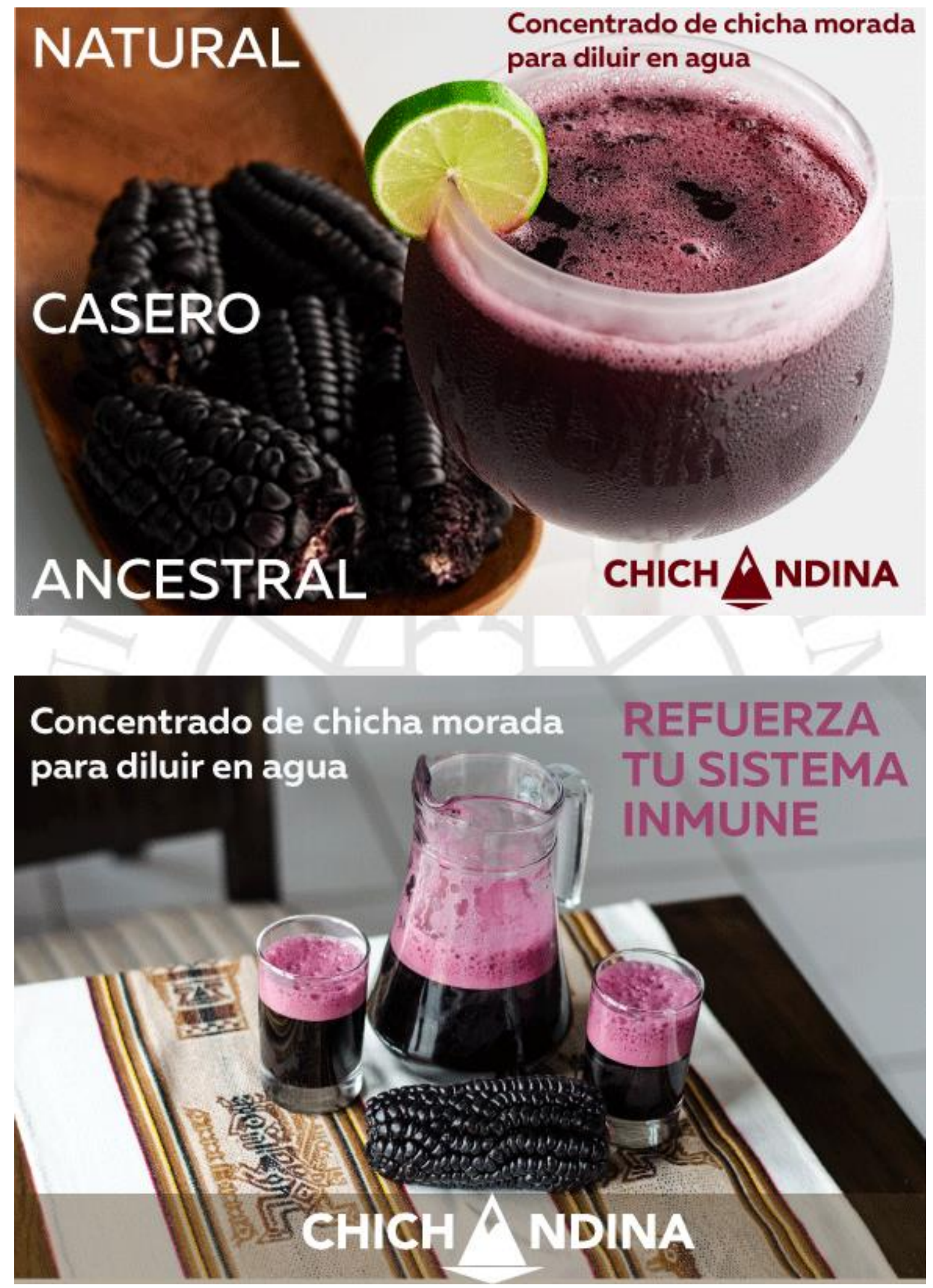

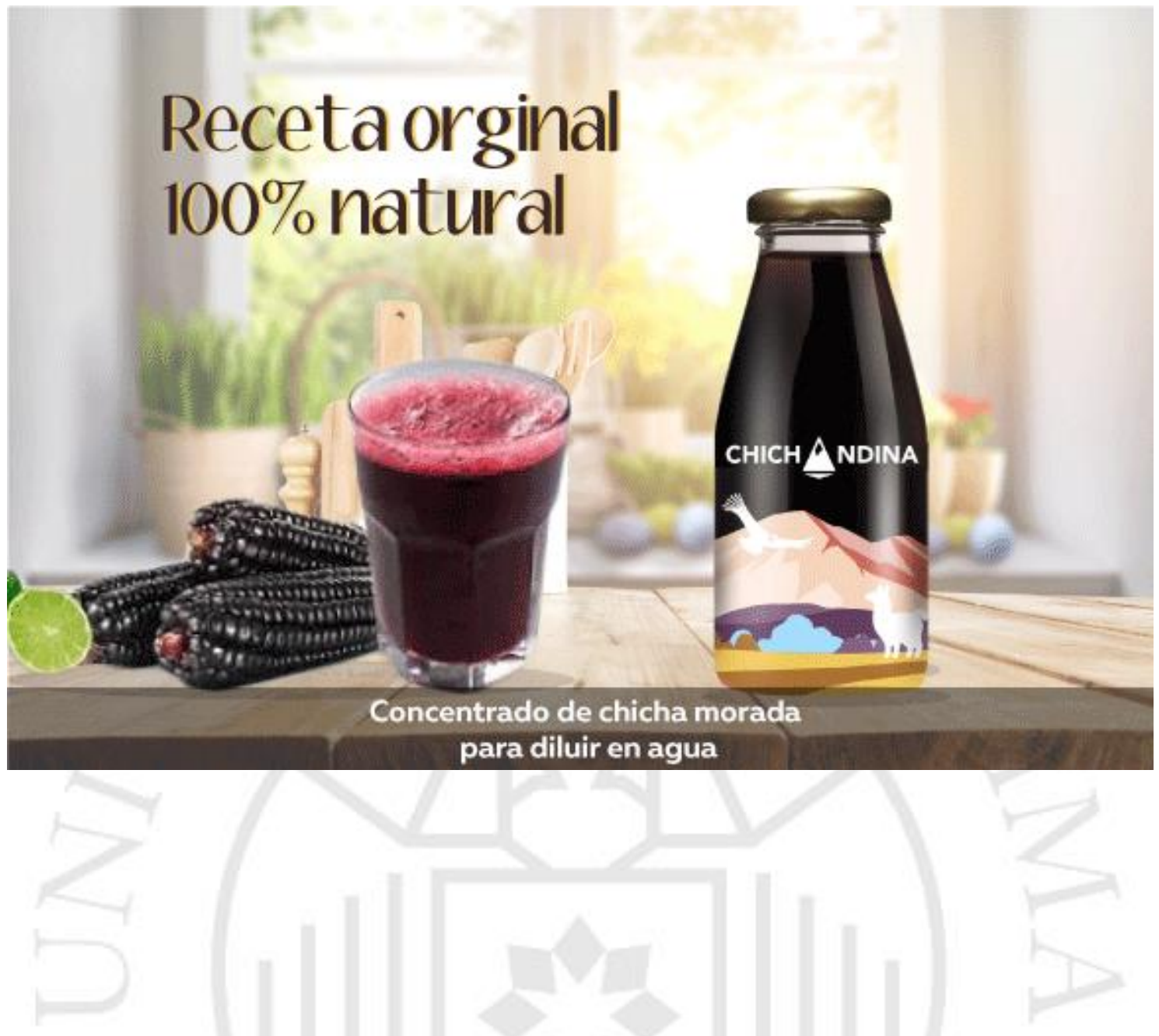

Los paneles de julio tendrán un mensaje distinto, apelarán a los atributos de Chicha Andina y a la vez reforzarán el patriotismo y el orgullo de haber nacido en nuestro país. A continuación, un ejemplo: 


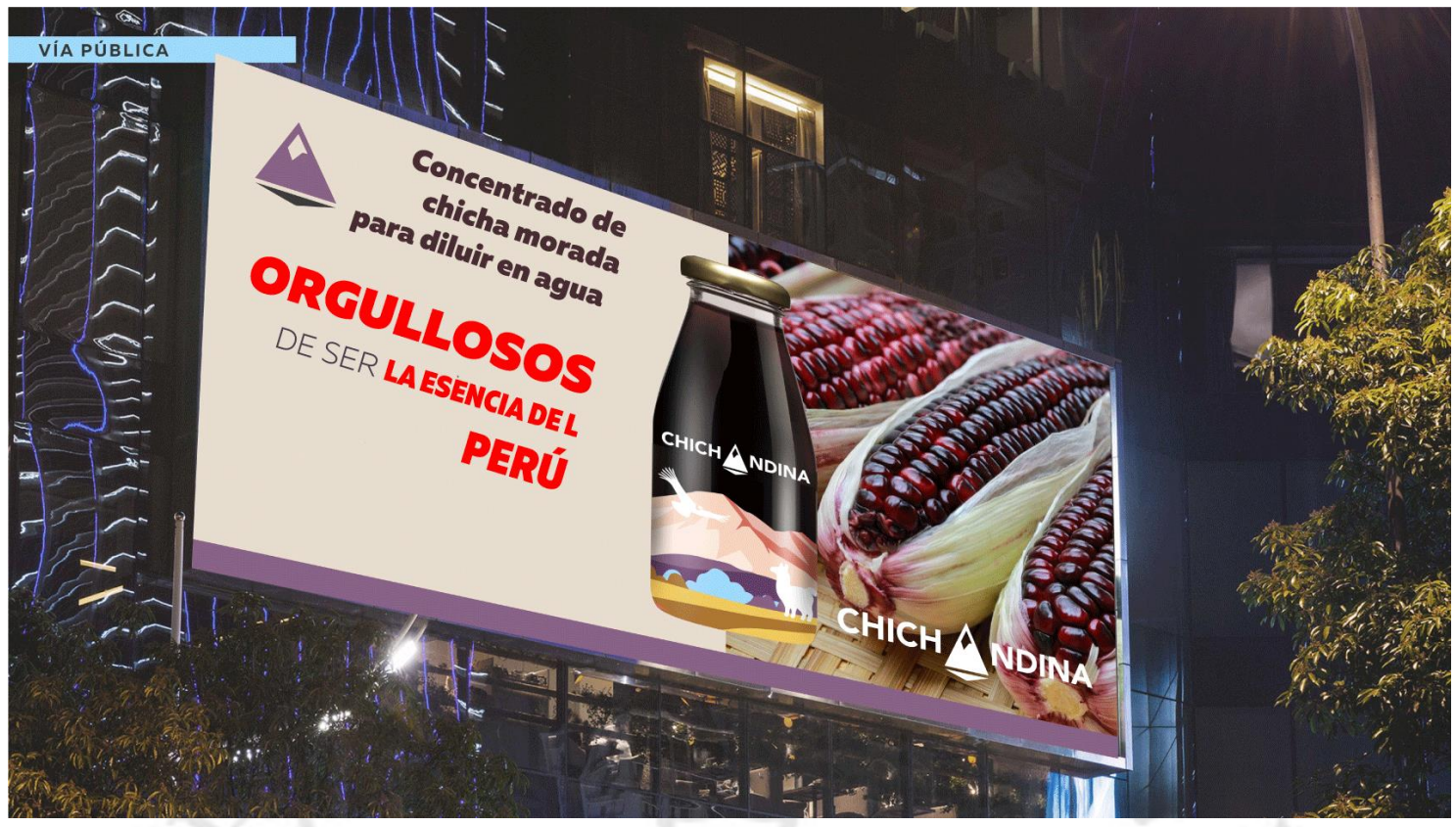

\subsection{Televisión}

Crearemos un spot publicitario, el cual permitirá mostrar las cualidades del producto y llegar a una gran audiencia a las amas de casa.

De vuelta al barrio es el programa líder en su horario. Se encuentra en el horario estelar que es de 7.00PM a 11.00PM, el cual se transmite de lunes a viernes de 8.30PM a 9.30PM por América TV, canal 4. Actualmente se sintoniza la tercera temporada de esta telenovela familiar. De vuelta al barrio es ambientado en los años 1978, en un barrio limeño. Busca revivir cómo eran las familias en los años setenta de manera divertida. El anuncio publicitario se emitirá los cinco días de la semana. En este programa colocaremos un spot de 30 segundos en la tanda comercial los cinco días de la semana en los que se transmite.

Los siguientes programas presentarán un product placement en su programa televisivo. Esta estrategia permitirá que la audiencia pueda observar atentamente nuestra marca gracias a la inserción de esta en la narrativa de los programas. Este product placement será de carácter activo con mención, ya que los personajes mostrarán los atributos positivos del producto y su forma de consumo. Esta estrategia tiene como objetivo llegar y conectar con las audiencias de forma emocional en los programas televisivos de manera más efectiva y menos intrusiva. 
Gisela - Artista del año: Uno de los programas más vistos de los sábados por las noches con la conducción de Gisela Valcárcel y en el cual participa un jurado. Donde los artistas son personas del medio local que se desenvuelven bailando y cantando en el programa. Se buscan que los participantes sean conocidos y de alguna manera mediáticos. Este programa se produce de 9.00PM a 11.30PM por América TV.

Movistar Plus, canal 6, muestra diversos contenidos como: moda, cultura, calidad de vida, gastronomía, viajes, entre otros. Hemos elegido que nuestra marca aparezca en el programa de Ximena en Casa, al finalizar la preparación de una comida peruana (lomo saltado) se mostrará Chicha Andina, Ximena lo diluirá en agua y lo servirá en un vaso para que sea el acompañamiento perfecto del plato icónico del Perú. Este programa está dirigido sobre todo a las amas de casa que cocinan día a día, que quieren recetas prácticas y deliciosas para mantener un estilo de vida saludable y nutrir a su familia con los mejores productos. Ximena Llosa es la chef del programa y lo que desea transmitir es que todos podemos cocinar, su objetivo es que las personas pierdan el miedo a cocinar y lo vean como algo fácil y entretenido. Además, sus programas son muy divertidos y Ximena suele invitar personas especiales al set para cocinar diversos platillos salados y dulces para diferentes tipos de acontecimientos o celebraciones. La transmisión del programa son los domingos a las 10:00am

Mi mamá cocina mejor que la tuya- canal 4, es un programa franquicia que se emite los domingos de 7.00PM a 8.00PM con la conducción de Ethel Pozo y Yako Eskenazi. Es un programa donde los invitados son personas relacionadas con el arte peruano y el espectáculo de la televisión. Siempre invitan a concursar a dos personas famosas y a las madres de ellos para realizar platos determinados en un lapso de tiempo establecido. Las mamás son aquellas que les indican a sus hijos cómo deben de preparar las comidas para que sepan exquisito, es decir las madres aportan la receta y las indicaciones, mientras que los hijos la "mano de obra". Además, el programa cuenta con un jurado que delibera quien gana, el premio se le otorga al mejor plato.

Yo Soy- es un programa de Latina, el cual se caracteriza por buscar talento de imitación de diferentes cantantes reconocidos a nivel mundial. Este programa cuenta con tres jurados: Ricardo Morán, Johanna San Miguel y Kattia Palma. Cuenta con la co- 
conducción de Christian Rivera. Este se transmite en horario estelar de 9:30 pm a 10:30 pm de lunes a viernes.

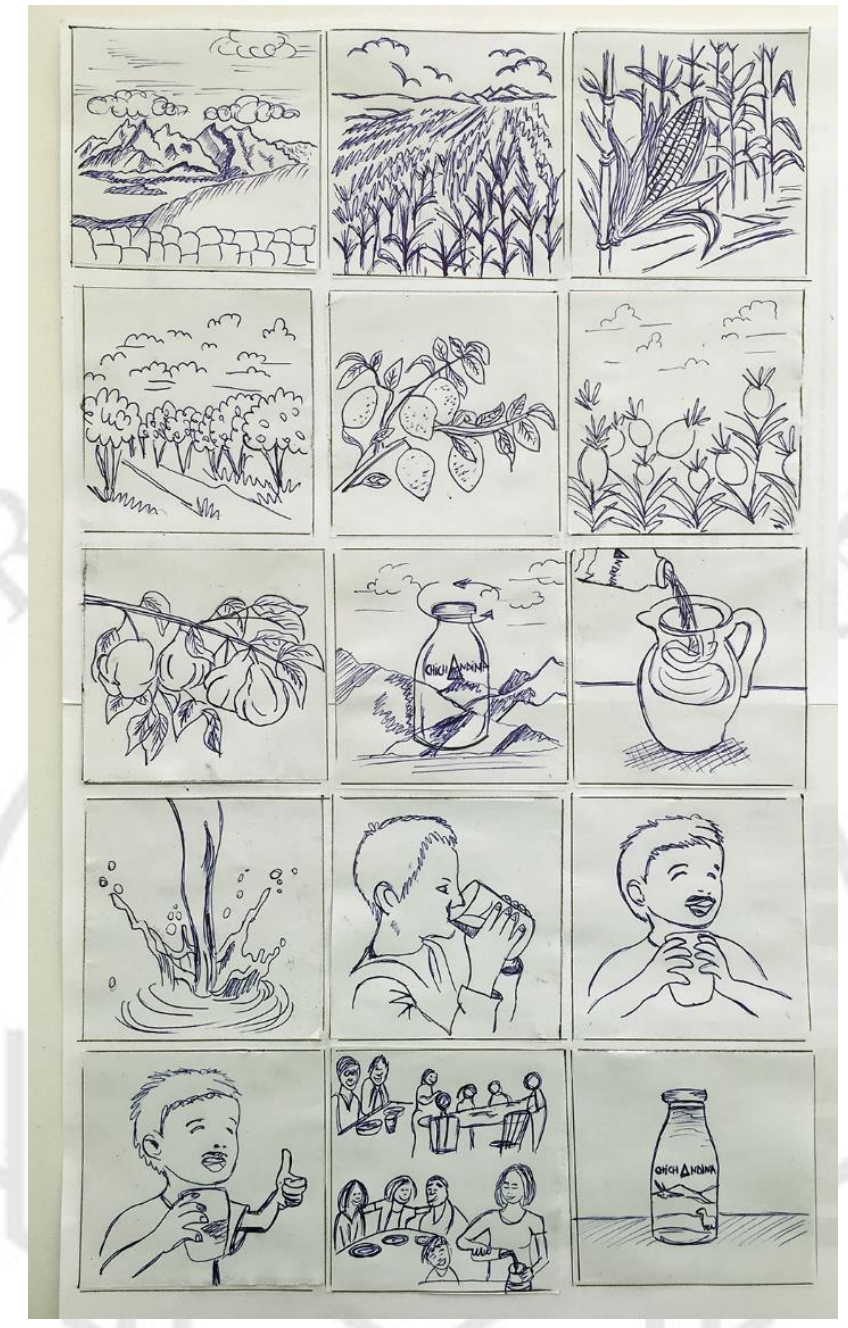

Spot televisivo de 30":

(Ver anexo)

El spot publicitario muestra la calidad de los insumos, en un ambiente situado en los Andes, en donde se muestra cada ingrediente bajo una música acústica andina, la cual transmite una sensación de paz y de bienestar. Luego, se observa cómo estos ingredientes se convierten en el concentrado de Chicha Andina, es ahí donde surge la botella de nuestra marca, mostrando el empaque que se asimila al paisaje antes visto en el panorama natural. Asimismo, se muestra cómo es que Chicha Andina se vierte en una jarra y se le agrega 2.5 litros de agua. Finalmente, se muestra a un niño tomando chicha y enfatizando su bigote de chicha, ya que este es un insight, todos alguna vez de niños nos hemos manchado por disfrutar de una deliciosa chicha y nuestras madres nos han limpiado. Además, el niño toma su vaso de chicha morada en su hogar y se observa cómo la disfruta, 
esto es justamente lo que buscan las amas de casa en cuanto a sus hijos, que tomen algo totalmente natural que potencie el organismo de sus hijos. Asimismo, se mostrará diferentes tipos de familias almorzando con el sabroso refresco casero Chicha Morada. Lo que deseamos bajo este spot publicitario es que nuestro público objetivo reconozca los beneficios y el delicioso sabor casero de Chicha Andina.

\section{$\underline{8.4 \text { Radio }}$}

Nuestro comercial de radio será pautado en RPP, Oxígeno y Planeta 107.7.

RPP, Radio Programas del Perú, es la emisora radial con más larga trayectoria en nuestra sociedad, ya que es la cadena radial con mayor cobertura a nivel nacional, además de ser muy sintonizada por los oyentes peruanos. Su público principal es de NSE A, B, C de 26 años a más. Asimismo, las emisoras de transmisión nacional ubican a RPP en el primer lugar en la audiencia total del Perú, llegando durante la semana al 25,3\% de toda la población desde los 11 años a más que estos interpretan a los 6,2 millones (4,9 a nivel urbano y 1,3 en el rural). (CPI, 2016)

Radio Oxigeno es la emisora 102.1, tiene como slogans clásicos del rock \& pop y emite música contemporánea tanto en inglés como en español de los años 70,80,90 y 2000. Es la radio favorita de NSE A, B y C. (CPI, 2016)

Planeta 107.7, es una emisora que solo produce música en inglés, en los géneros de pop, hip hop y electro pop. Es una radio juvenil que es escuchada por los sectores A, B y C, siendo muy acogida por la buena onda de sus locutores. (Gestión, 2018)

El spot radial de lanzamiento de Chicha Andina tendrá un sonido de fondo de instrumentos acústicos andinos, los cuales darán una sensación de naturaleza y paz. El objetivo es posicionar la marca como algo puro y local, de la cual las personas se sientan orgullosas y quieran ser parte de un estilo de vida saludable. Este spot tiene una duración de 20 segundos. 
A continuación, el spot radial:

"Somos un Todo,

Somos un país,

Somos los Andes,

Somos su esencia,

Somos familia,

Somos Chicha Andina,

Tu concentra de chicha morada,

$100 \%$ natural".

\begin{tabular}{|c|c|c|c|c|c|c|c|c|c|}
\hline & & & & & & & & & \\
\hline & & Lunes & Martes & Miercoles & Jueves & Viemes & $\begin{array}{c}\text { Total } \\
\text { anuncios }\end{array}$ & $\begin{array}{l}\text { Tarifa por } \\
\text { anuncio }\end{array}$ & $\begin{array}{c}\text { Total } \\
\text { inversion }\end{array}$ \\
\hline Intriga & Semana 1 & & & & & & & & \\
\hline RPP & \multirow{3}{*}{ Semana 2} & 4 & 4 & 4 & 4 & 4 & 20 & $\$ 400$ & $\$ 8,000$ \\
\hline Oxigeno & & & 4 & & 4 & & 8 & $\$ 121$ & $\$ 970$ \\
\hline Planeta 107.7 & & 4 & 4 & 4 & 4 & 4 & 20 & $\$ 121$ & $\$ 2,424$ \\
\hline RPP & \multirow{2}{*}{ Semana 3} & 4 & 4 & 4 & 4 & 4 & 20 & $\$ 272$ & $\$ 5,432$ \\
\hline Oxigeno & & & 4 & & 4 & & 8 & $\$ 121$ & $\$ 970$ \\
\hline Planeta 107.7 & \multirow{2}{*}{ Semana 4} & 4 & 4 & 4 & 4 & 4 & 20 & $\$ 121$ & $\$ 2,424$ \\
\hline Oxigeno & & & 4 & & 4 & & 8 & $\$ 121$ & $\$ 970$ \\
\hline RPP & \multirow{2}{*}{ Semana 5} & 4 & 4 & 4 & 4 & 4 & 20 & $\$ 272$ & $\$ 5,432$ \\
\hline Planeta 107.7 & & 4 & 4 & 4 & 4 & 4 & 20 & $\$ 121$ & $\$ 2,424$ \\
\hline RPP & \multirow{3}{*}{ Semana 6} & 4 & 4 & 4 & 4 & 4 & 20 & $\$ 272$ & $\$ 5,432$ \\
\hline Planeta 107.7 & & 4 & 4 & 4 & 4 & 4 & 20 & $\$ 121$ & $\$ 2,424$ \\
\hline Oxigeno & & & 4 & & 4 & & 8 & $\$ 121$ & $\$ 970$ \\
\hline RPP & \multirow{3}{*}{ Semana 7} & 4 & 4 & 4 & 4 & 4 & 20 & $\$ 272$ & $\$ 5,432$ \\
\hline Planeta 107.7 & & 4 & 4 & 4 & 4 & 4 & 20 & $\$ 121$ & $\$ 2,424$ \\
\hline Oxigeno & & & 4 & & 4 & & 8 & $\$ 121$ & $\$ 970$ \\
\hline RPP & \multirow{3}{*}{ Semana 8} & 4 & 4 & 4 & 4 & 4 & 20 & $\$ 272$ & $\$ 5,432$ \\
\hline Planeta 107.7 & & 4 & 4 & 4 & 4 & 4 & 20 & $\$ 121$ & $\$ 2,424$ \\
\hline Oxigeno & & & 4 & & 4 & & 8 & $\$$ & $\$ 970$ \\
\hline \multicolumn{2}{|c|}{ Total anuncios } & & & & & & 288 & $\$ 3,212$ & $\$ 55,176$ \\
\hline
\end{tabular}

\subsection{Prensa}

Este medio será de gran ayuda para la campaña, ya que nos permitirá informar a los lectores sobre las cualidades e información nutricional de Chicha Andina. Se seleccionó la revista Somos y el diario El Comercio con publicación los sábados y domingos respectivamente, ya que son los días que suelen hacer las compras en supermercados las amas de casas. Esta estrategia nos permitirá recordar la presencia del producto.

En los dos meses de campaña, pagaremos 4 anuncios en la Revista Somos, su publicación son los sábados y viene gratis cuando adquieres el diario El Comercio. Las semanas de la campaña donde los publicaremos serán la segunda, tercera, cuarta y sexta. Esta tiene mayor cercanía a personas de NSE AB hombres y mujeres, asimismo existe una mayor afinidad con un 59\% a mujeres. Esta revista muestra en su diagramación imágenes con 
colores vivos y de buena calidad, además muestra contenidos para diferentes públicos según estilo de vida, intereses y más. (ECO Media, 2016). La revista va a contar con un anuncio donde se perciba el producto total, de tal manera que tenga una mayor presencia y llame más la atención del público lector. La inversión total de estos anuncios será de S/. $61,135.52$

Con respecto al diario El Comercio realizaremos anuncios tres domingos de la campaña. Este día es cuando tiene mayor lectoría del público. Estos serán publicados en la segunda, quinta y octava semana. Este periódico es considerado como uno de los favoritos de los NSE A y B, hombres y mujeres de 26 años a más. Se percibe como un diario serio, formal y con contenido variado de las últimas noticias. Cuenta con espacios de política, fútbol, cartelera, economía, mundo, tecnología y más. (ECO Media, 2016) La inversión total de los anuncios será de S/. 114,902.52

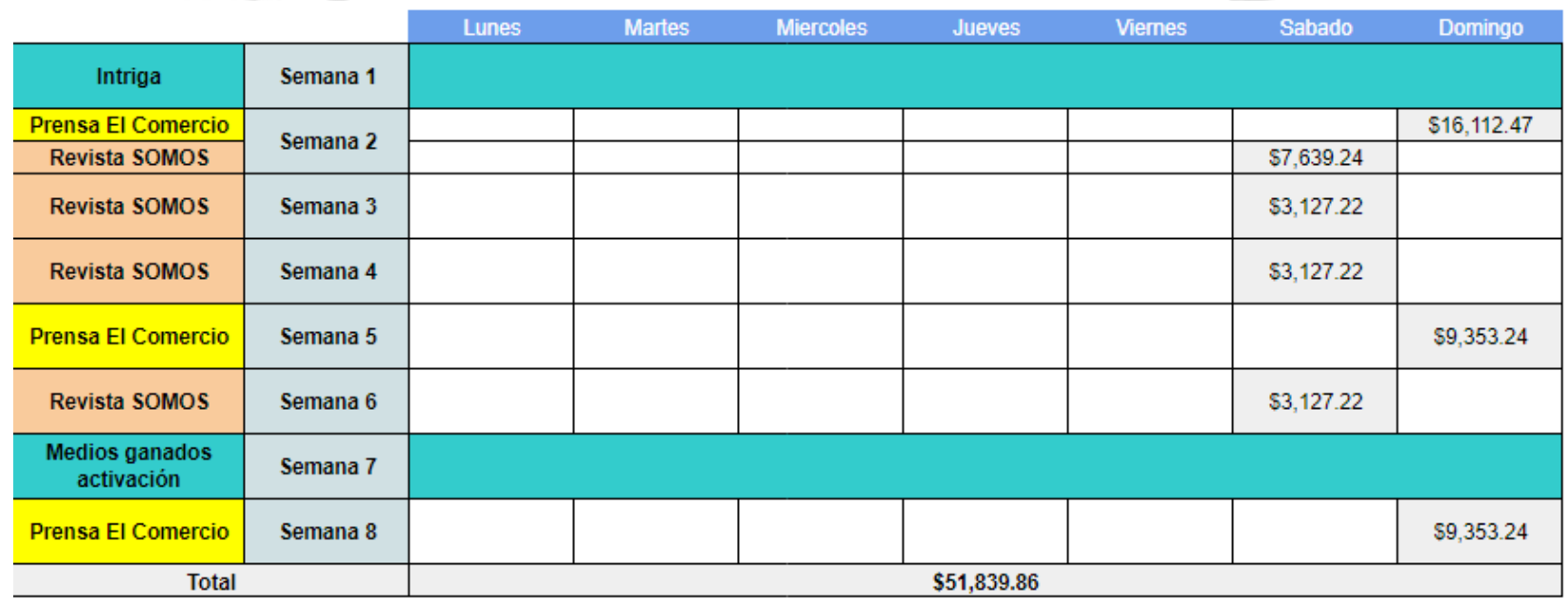

\section{$\underline{\text { 8.6 Digital }}$}

\subsubsection{Facebook}

La página de Facebook de Chicha Andina tendrá contenido sobre la marca y su origen, además mencionará la página web oficial www.chichandina.pe. Se destinarán 18,200 dólares del presupuesto para promocionar las publicaciones de esta plataforma. El diseño y estilo de la página de Facebook, mostrará una conexión los gustos e intereses de nuestro público objetivo, utilizará un lenguaje amical y coloquial. Nuestro Community Manager, estará siempre pendiente y 
atento a contestar las dudas y preguntas que tengan sobre nuestro producto. Durante estas ocho semanas de campaña, se realizarán publicaciones diarias con pauta en Facebook.

Nuestro público objetivo se caracteriza por estar muy pendiente a lo que pasa en las redes sociales, siendo Facebook la red que es más afín a ellas, donde se conectan con sus amigas, familiares y encuentran muchas publicaciones que les interesa, se enteran de los productos que se ofrecen al mercado y las ofertas que hay en los supermercados.

Las influencers tendrán un papel fundamental en esta red, ya que postearán a manera de noticia los beneficios de nuestro producto.

El sorteo que se realizará será de una estadía doble en Cusco en el hotel Belmond con todo incluído. Podrán participar de un tour personalizado el cual tendrá como objetivo visitar Machu Picchu y nuestras cosechas de maíz morado. La ganadora se anunciará por esta plataforma, ya que es la más relevante en la vida de nuestro target. Los pasos para ganar son: seguir a Chicha Andina en Facebook, Instagram y etiquetar a la persona con la quieren viajar y decir con qué asocias la chicha morada.

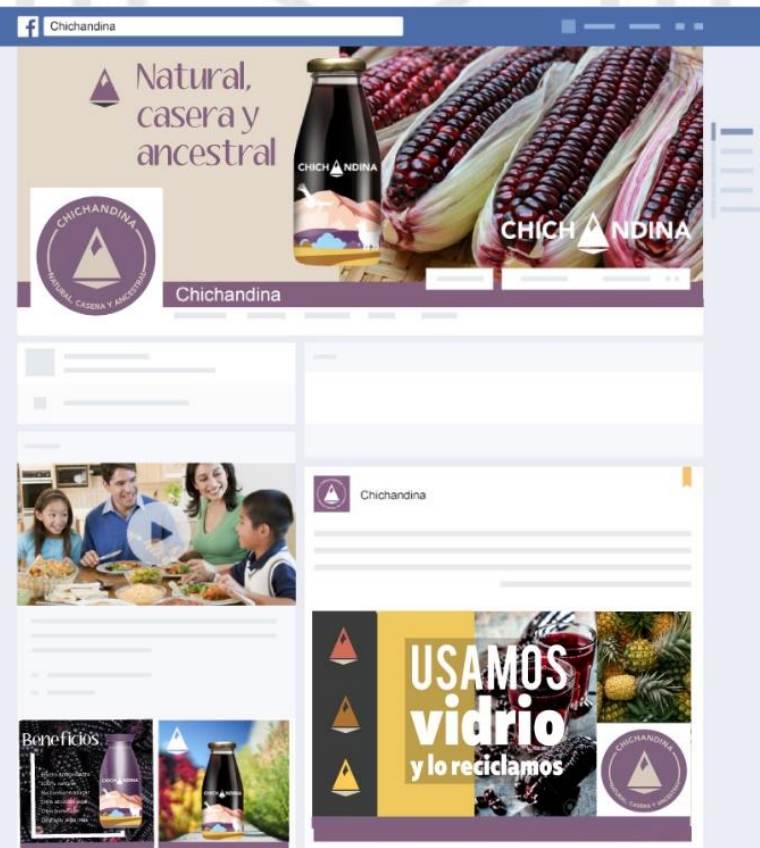




\subsubsection{Instagram}

Instagram es una plataforma está empezando a ser parte de nuestro público objetivo, lo ven como algo nuevo, pero ya lo están aprendiendo a manejar mucho mejor que antes.

Es por eso que se destinarán 5,200 dólares durante los dos meses de la campaña de lanzamiento, la cual se encargará de transmitir los valores de la marca, su personalidad y establecer interacción con la comunidad que estamos adquiriendo. Esta red social estará fuertemente conectada con las influencers elegidas. Ellas cuentan con muchos seguidores y acogida, nos encargaremos de replicar sus historias y fotografías. Además, en la cuarta y quinta semana promocionaremos el sorteo del pasaje a Cusco para dos personas todo incluido en el hotel Belmond, en el cual visitarán Machu Picchu y se le hará tour por nuestras cosechas de maíz morado, y donde podrán disfrutar de la naturaleza y su gastronomía. El sorteo consta de los siguientes pasos: seguir nuestras plataformas de Instagram, Facebook y etiquetar a tres amigos en el post. El resultado de la ganadora se revelará en la sexta semana de la campaña.

Los posts de las otras semanas de la campaña crearán otro tipo de interacción con nuestro público objetivo el cual buscará generar un lazo mucho más amical que informativo, donde las influencers cuenten sus experiencias con el producto. Además, Chicha Andina transmitirá contenido valioso para nuestro público objetivo, en el cual se encontrarán tips, notas de expertos en nutrición, salud y aventuras que hay para descubrir en nuestro país. 


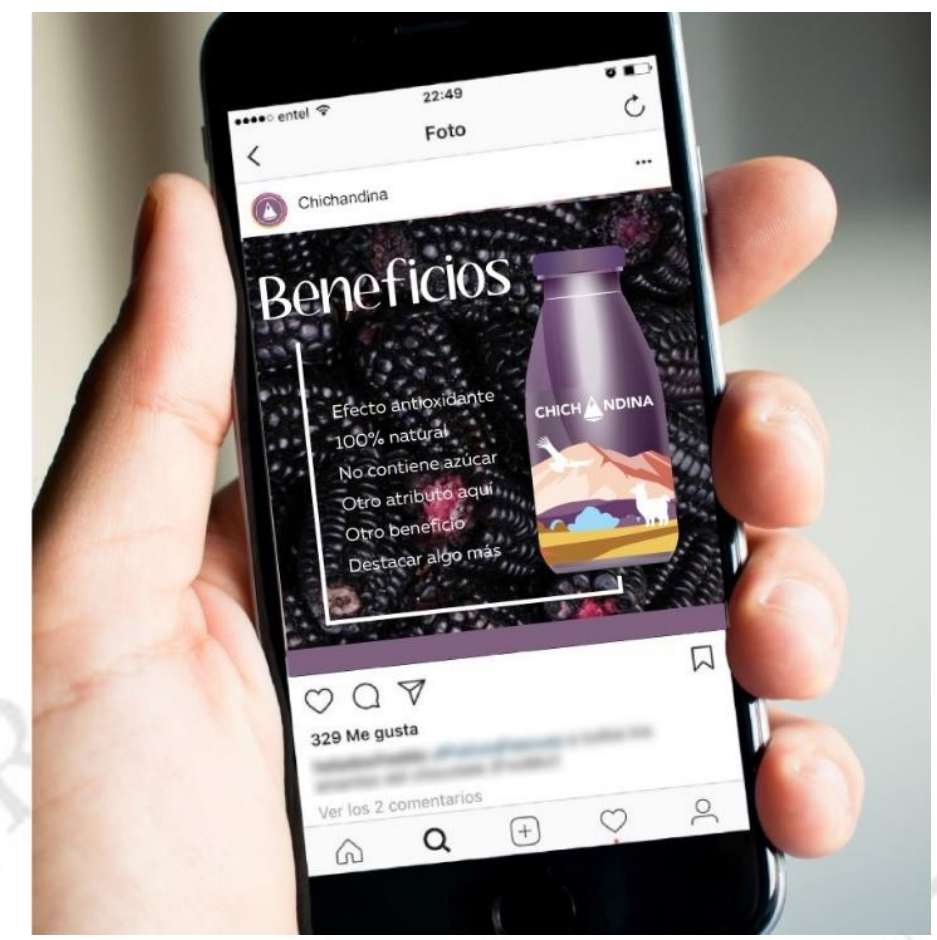

\subsubsection{Página web}

El diseño de nuestro sitio web será responsive, ya que nuestros activos deben visualizarse de forma que sean capaces de satisfacer las necesidades del cliente en cada dispositivo. Los contenidos que colocaremos permitirán multiplicar la visibilidad de nuestra marca a través de las distintas plataformas como redes sociales, los buscadores y otros canales. Asimismo, mejoran la imagen de marca (branding) y ayudan a que mejore su posicionamiento. Tendremos un blog dentro de nuestra página web, el cual se encontrará en una de nuestras pestañas. Tres veces a la semana estaremos publicando contenido relevante sobre cómo llevar una buena alimentación, tips de loncheras saludables y más. El contenido debe educar y mostrar temas de interés de nuestro público objetivo, esto ayudará en el SEO de nuestra página web al igual que aumentará el crecimiento del tráfico en el sitio web, las oportunidades de venta y las ventas. 

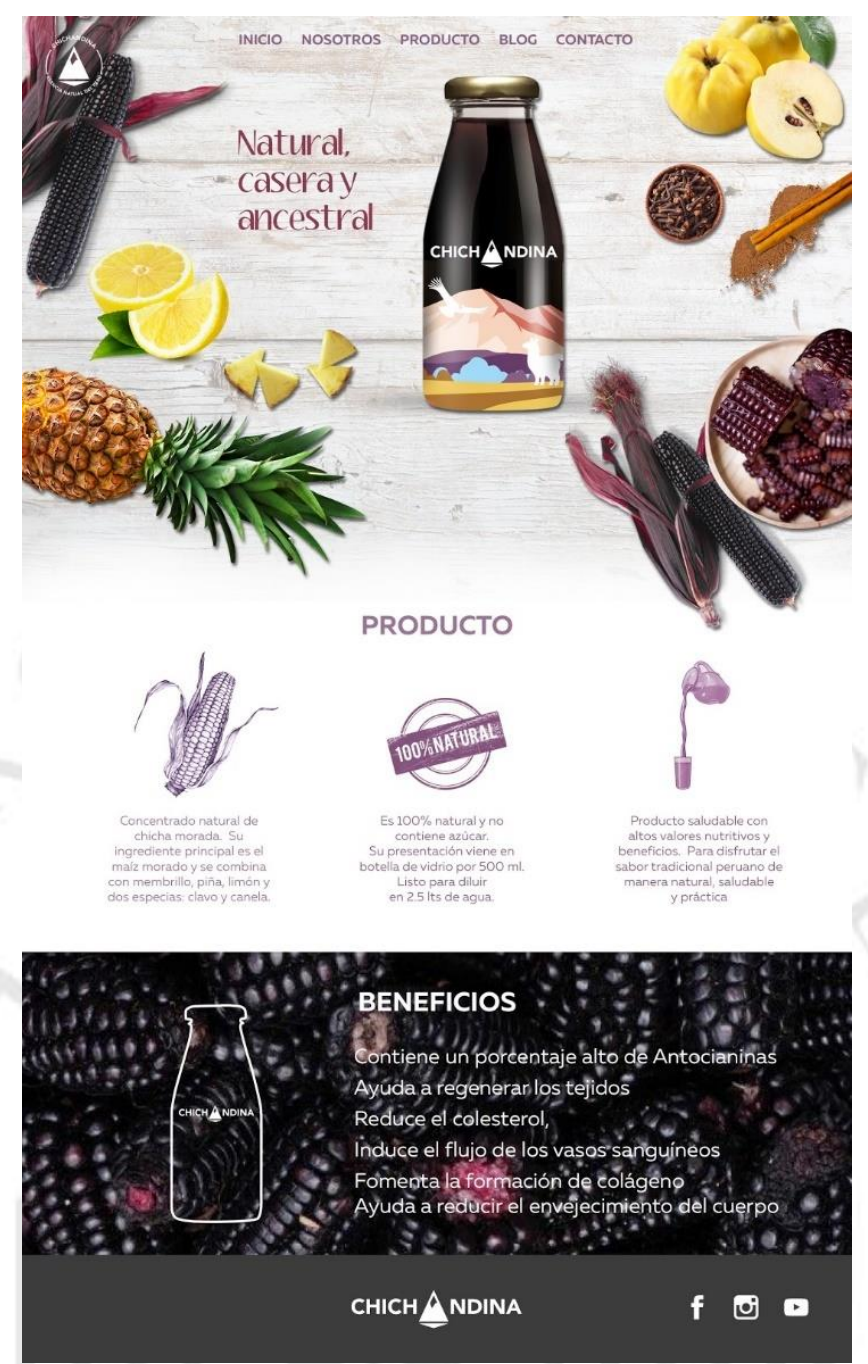

8.6.4 SEO

El Search Engine Optimization (SEO) busca optimizar tu página web en los resultados de búsqueda a través de contenidos de valor para las audiencias, los cuales contengan palabras clave que sean utilizadas por estas. El principal objetivo del SEO es aumentar el volumen del tráfico orgánico de páginas web, blogs y publicaciones. El SEO se centra en el usuario, ya que tiene como principal fin ayudar a encontrar soluciones a sus necesidades, su forma de buscar respuestas y los resultados que el cliente espera al indagar algo. (Redacc, 2017)

Además, en nuestra página web mostraremos los beneficios de tomar chicha morada natural, las prevenciones de enfermedades que esta tiene y los usos que podemos darle a las botellas de Chicha Andina. La botella al ser de vidrio reciclado muestra un aspecto vintage, por lo que puede ser usado como un artículo 
decorativo en casa, por ejemplo, se pueden colocar plantas y emplearlo de florero, o sembrar plantas, ya que el diseño de la botella es de pico ancho y con un embudo sería muy fácil de colocar la tierra y las semillas.

Dentro de la pestaña que se llamará "Nosotros" contaremos sobre nuestra historia, cómo es que nació Chicha Andina, cómo apoyamos a nuestros agricultores. Además, se mostrará la visión, misión y valores de la empresa. Es muy importante que nuestro público sepa quiénes somos y nuestro compromiso con nuestros clientes, colaboradores y medio ambiente.

En nuestro sitio web, al lado derecho, se encontrarán los logos de nuestras redes sociales (Facebook, Instagram y YouTube), las cuales están linkeadas a cada una de ellas para que nuestros clientes entren directamente a ver el contenido de cualquiera de estos tres medios.

Tendremos una pestaña que se llamará "Encuéntranos", donde pondremos con signos de localización todos los puntos de ventas de los supermercados y tiendas orgánicas y la dirección de cada una de ellas con referencias para llegar.
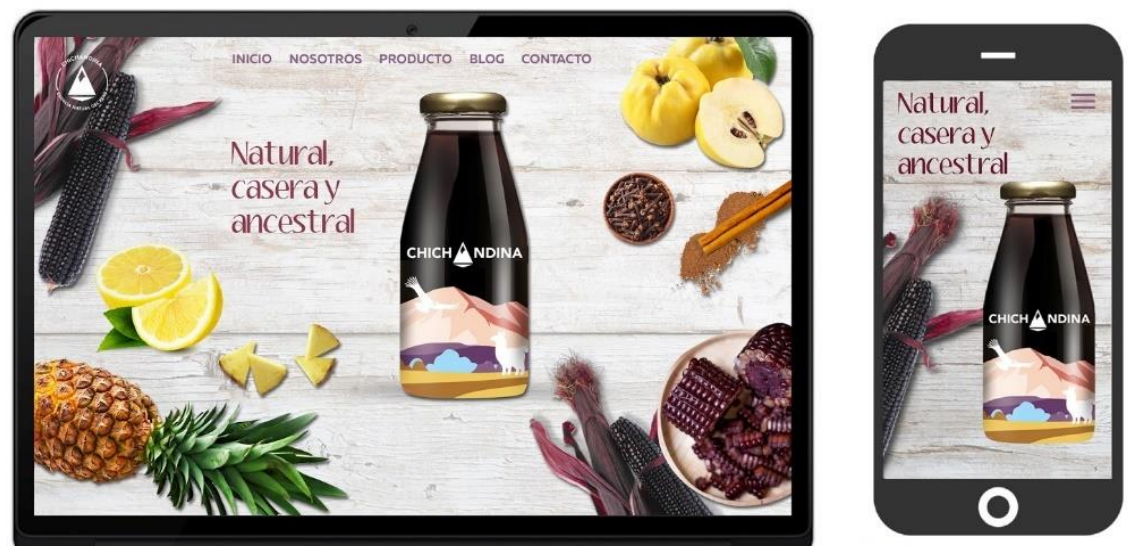


\subsubsection{SEM}

El Search Engine Marketing (SEM) es esencial para crear presencia online rápidamente y a su vez captar la atención de los usuarios al momento de ejecutar alguna búsqueda en Google. (Brito, 2017)

Respecto a las palabras claves, hemos elegidos las que han sido parte de Chicha Andina como chicha morada, chicha peruana, maíz morado, refresco peruano, chicha andina, bebida natural. Estas palabras buscan poder llegar a nuestro target rompiendo el desconocimiento y ofreciendo información valiosa.

Además, también se utilizará la red display de Google y en YouTube. Estos anuncios nos posibilitarán mostrar ser más dinámicos con videos en YouTube y con formatos de imagen en diversos sitios web. Los formatos pueden variar, pero siempre redireccionarán a nuestro sitio web www.chichandina.pe

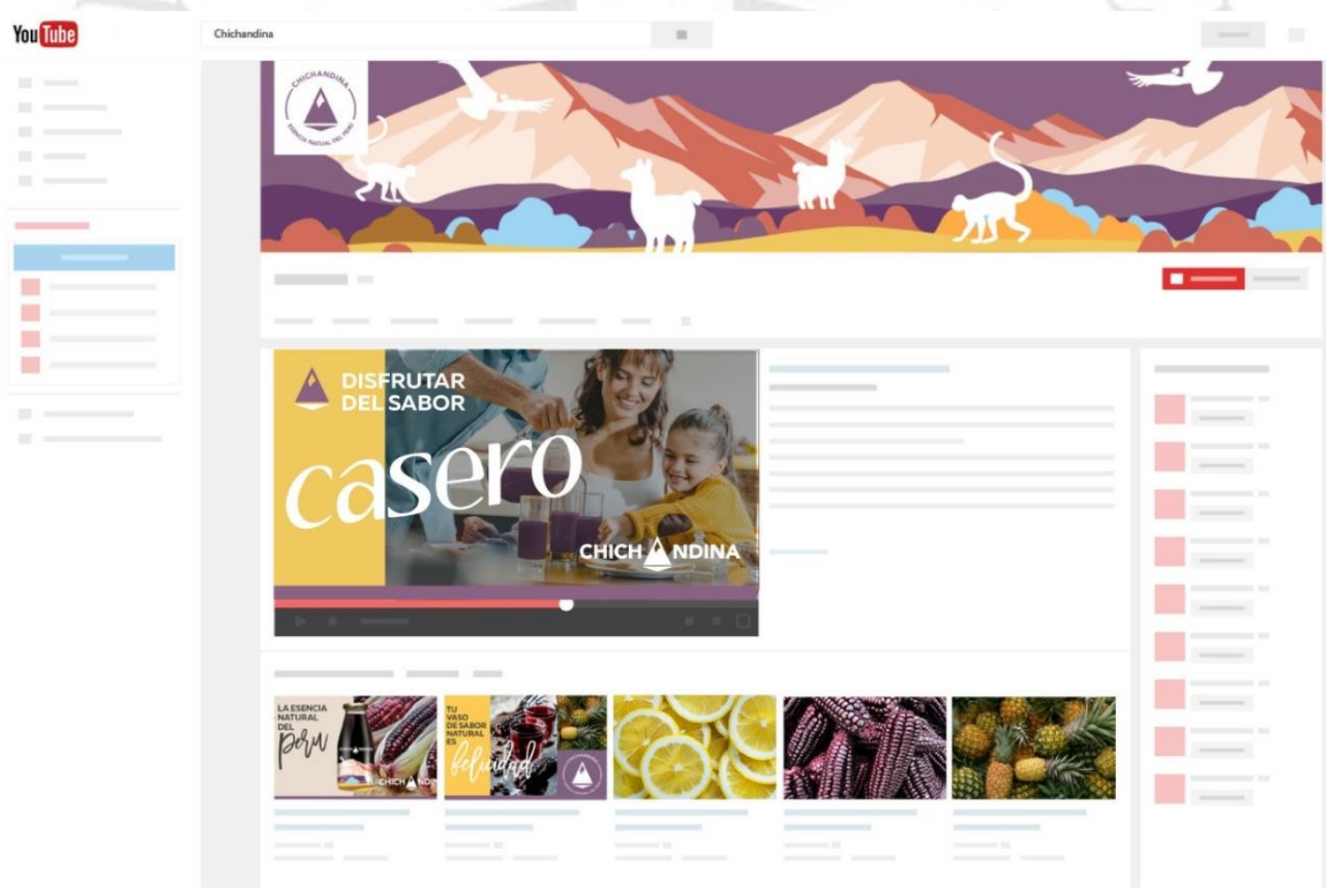

\section{$\underline{8.7 B T L}$}

Realizar acciones BTL serán de gran utilidad para ganar un mayor contacto y cercanía con nuestro público objetivo, ayudándolos a tener más información sobre el producto que estamos ofreciendo y a generar recordación en las personas con las acciones que presentaremos a continuación. 
Se contará con impulsadoras en diez supermercados en Miraflores, San Isidro, La Molina, Surco, San Borja y Magdalena. Y cinco tiendas orgánicas entre estos distritos y Barranco que se encuentra La Sanahoria, Flora y Fauna, Mara Bio Market, La Colorada y Punto Orgánico. Lo que queremos lograr con esta estrategia es acercar el producto a nuestro target, llamando la atención de ellas por medio de nuestras activaciones, haciendo que prueben el producto, sepan qué contiene y cómo se debe preparar. Además, que deseamos que participen de las diferentes dinámicas que colocaremos en los supermercados y tiendas asignados.

\subsubsection{Activaciones junio 2019}

\section{- Semana 1: músicos con instrumentos acústicos andinos y degustación}

En diez supermercados limeños haremos una degustación de nuestro producto con dos anfitriones. Además, nos acompañarán el sábado, por tres horas, de 5PM a 8PM, músicos que tocarán instrumentos musicales andinos. Asimismo, en los cinco establecimientos de tiendas orgánicas seguiremos realizando las degustaciones de nuestro producto con una anfitriona que dará a conocer los beneficios de Chicha Andina. Las pruebas del producto reforzará la acción de los mensajes publicitarios es decir se reafirmarán los atributos de Chicha Andina en el gusto del mercado meta.

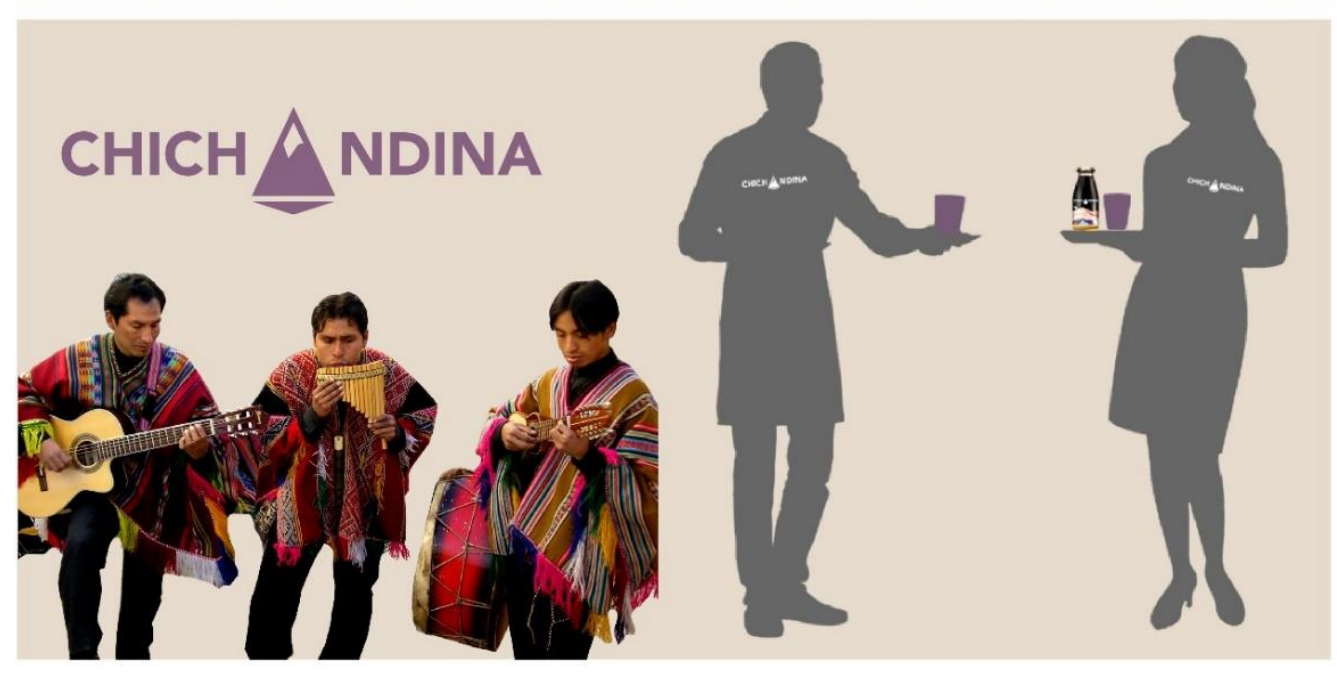




\section{- Semana 6: Maratón Life Lima 42K Nike - Chicha Andina}

Seremos auspiciadores de la maratón Life $42 \mathrm{k}$ de $42 \mathrm{~K}, 21 \mathrm{~K}, 10 \mathrm{~K}$ y $5 \mathrm{~K}$ con alianza de Nike, donde nuestro principal objetivo es ganar medios, todo tipo de prensa escrita, radial y digital. Lo que buscamos es tener una mayor exposición de nuestra marca ofreciendo una experiencia que va de acorde al estilo de vida saludable que ofrecemos. Esta alianza con Nike, una marca deportiva, tendrá una gran acogida en el mercado y apostamos en estar presente en un acto saludable, haciendo conocida nuestra marca y teniendo además un módulo donde se dará a degustar nuestra chicha morada.

Además. contaremos con nuestras influencers que al tener un estilo de vida muy saludable tienen como parte de su rutina salir a correr y participar en las diferentes maratones que se dan en Lima en todo el año. Por eso, ellas serán las embajadoras de la marca utilizando sus redes sociales en todo momento desde que van a la carrera hasta que finalizan. Además, estarán todas nuestras influencers en el módulo de Chicha Andina donde tendrán momento de tomar nuestro delicioso producto y conversar con nuestra audiencia.

Esta carrera se dará en el Pentagonito a las 8 de la mañana del domingo de la sexta semana de nuestra campaña, donde tendremos una tribuna exclusiva de Chicha Andina para que las personas que acompañen a los participantes se puedan sentar para ver la llegada de estos.

Además,en el podio y banner de los primeros puestos estará el slogan de nuestra marca y tendremos a dos anfitrionas que les concederán una canasta con nuestro producto y merchandising

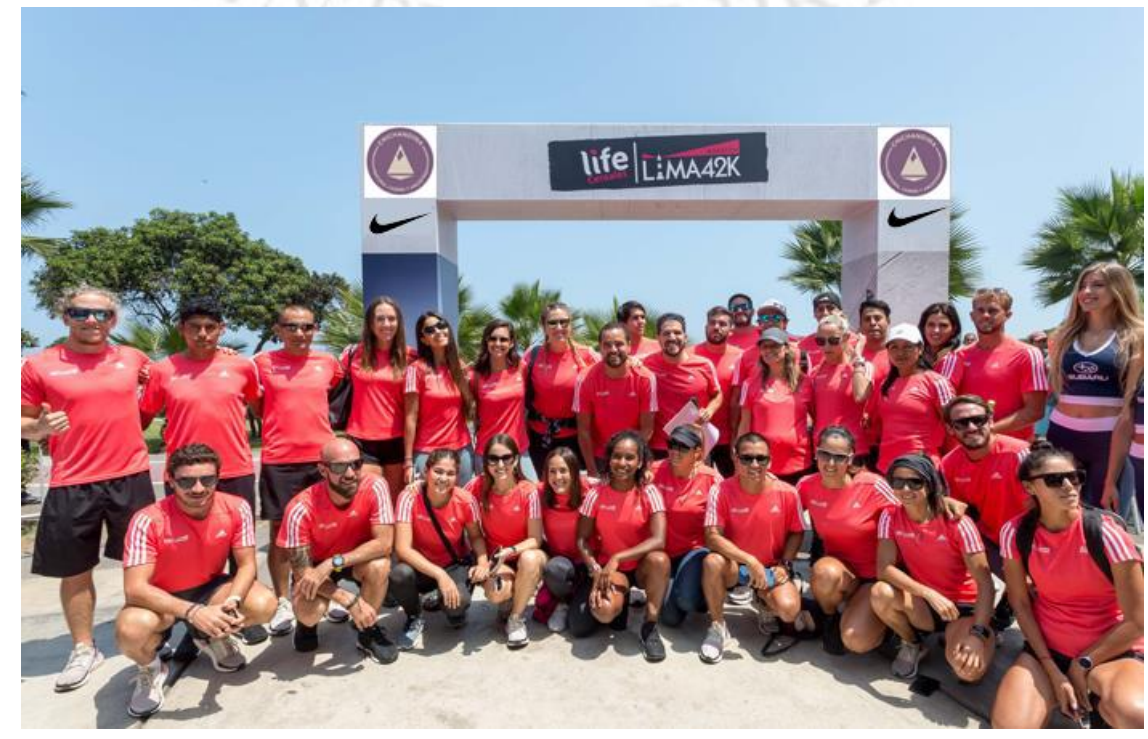




\section{CONCLUSIONES}

Chicha Andina busca transmitir su idea de marca: Con Chicha Andina, el auténtico sabor casero, mantén una alimentación sana y consciente., la cual le da un sentido de estilo de vida saludable y del gusto por el sabor casero y natural de una receta nacional. Al ser un producto local, Chicha Andina respalda a los agricultores y muestra total transparencia en su empaque acerca de los ingredientes que se utilizan para la realización de un concentrado saludable y rico en propiedades beneficiosos para la salud.

Además, el atributo principal de Chicha Andina es ser un refresco 100\% natural como hecho en casa. Marca un estilo de vida saludable, el cual es tendencia hoy en día, y, el cual, se debe tener conciencia para sentirse bien y vivir mejor.

Estos conceptos serán utilizados en campañas posteriores a la de lanzamiento, ya que destacan la propuesta de valor y las ventajas diferenciales del producto, los cuales generarán ánimo en personas más activas y conscientes en probar un refresco icónico del Perú de alta calidad, con sabor casero y que beneficie su salud. Chicha Andina en su campaña de lanzamiento busca ser posicionada como una marca responsable con el planeta, ya que esta utiliza botellas de vidrio reciclado. Existe una preocupación por un futuro sostenible, por lo que la marca intenta educar e informar distintas formas de ayudar al medioambiente a través de su blog y sus redes sociales. Chicha Andina tiene el potencial de ser la empresa líder de chicha morada en el Perú, ya que busca ser percibida emocionalmente como una bebida emblema del Perú, la cual contiene el mejor sabor casero e insumos naturales de los Andes.

El plan de comunicación está enfocado en su campaña de lanzamiento de dos meses en Lima. Ya que se desea utilizar esta estrategia para cautivar y ver la respuesta de nuestro público limeño, para luego ingresar con fuerza a provincias. La estrategia de medios se basa en una campaña $360^{\circ}$ online y offline la cual busca un reconocimiento hacia la marca, que genere ventas y logre posicionarse en el mercado y generando confianza y lealtad. 


\section{RECOMENDACIONES}

Proponemos evaluar la posibilidad de continuar con una campaña de mantenimiento en Lima, mientras realizamos la campaña de lanzamiento en provincias, con activaciones en los principales centros comerciales de las ciudades, así como en espacios de punto de venta. Estos eventos tendrán el objetivo atraer tráfico e interacción con la marca, asimismo podremos posicionar nuestro producto dando a conocer sus valores y personalidad. Se recomienda seguir realizando alianzas con influencers orgánicamente enviando el producto para que realicen unboxings para sus comunidades.

Además, planteamos auspiciar ferias gastronómicas a nivel nacional y Mistura, las cuales buscan potenciar el valor de productos naturales y peruanos respectivamente. En julio, al igual que en nuestra campaña de lanzamiento, proponemos se realice una estrategia basada en el mes patrio, valorizando lo nuestro y lo orgullosos que estamos de ser peruanos.

En diciembre, recomendamos una estrategia más agresiva en Lima, ya que es la época en donde comienza el verano, previa a Navidad, donde se suelen concretar gran cantidad de reuniones familiares. Asimismo, se plantea ampliar los puntos de venta al sur y colocar paneles publicitarios en el trayecto de la Panamericana Sur y puntos de venta en el Boulevard de Asia, en los stands que se encuentran dentro del establecimiento y en el sur chico como Punta Hermosa, San Bartolo, Naplo y Santa María hacer alianzas con las tiendas más concurridas por los veraneantes de la zona. 


\section{REFERENCIAS}

ADESIGN PERU. (16 diciembre, 2010) Re: Paletas de Colores Cromáticos [Post en un blog] Recuperado de https://adesignperu.blog/2010/12/16/paletas-de-colorescromaticos/

Andina. (2014, 29 octubre). El $55 \%$ de amas de casa en Lima es internauta y tiene cuenta de Facebook. Recuperado de https://andina.pe/agencia/noticia-el-55-amas-casa-lima-esinternauta-y-tiene-cuenta-facebook-529436.aspx

Arellano. (2017). Los seis Estilos de Vida. Recuperado de https://www.arellano.pe/losseis-estilos-de-vida/

Arellano. (2017). Las Modernas. Recuperado de https://www.arellano.pe/los-seis-estilosde-vida/las-modernas/

Brito, Glismir. (23 mayo, 2017) Re: SEM: Qué es, Tipos y Todo lo que Debes Saber. [Post en un blog]. Recuperado de https://www.genwords.com/blog/sem

CPI. (2016). Audiencias Radiales 2016. Recuperado de https://www.cpi.pe/images/upload/paginaweb/archivo/26/mr_resumen_anual_audiencia radial_2016.pdf

DATUM. (2018). La mujer en el Perú. Recuperado de http://www.datum.com.pe/new_web_files/files/pdf/La_mujer_en_el_Peru.pdf

DATUM. (2017). Vida Saludable ¿Yo?. Recuperado de http://www.datum.com.pe/new_web_files/files/pdf/Vida-Saludable.pdf

Diario Correo. (2018, 8 junio). Mujeres peruanas toman el $80 \%$ de las decisiones en el hogar, según Ipsos. Recuperado de https://diariocorreo.pe/peru/mujeres-peruanas-toman80-decisiones-hogar-segun-ipsos-823533/

ECO Media. (2016). Tarifario Actualización El Comercio 2016. Recuperado de http://e.gec.pe/67/doc/0/0/7/4/7/747497.pdf

ECO Media. (2015). ¿Cuáles son los hábitos y actitudes de los peruanos hacia los medios impresos? Recuperado de http://e.gec.pe/67/doc/0/0/7/4/7/747497.pdf

EcuRed. (2017).Maíz morado Recuperado de https://www.ecured.cu/Ma\%C3\%ADz_morado

El Comercio. (2014, 30 octubre). ¿Cómo se comportan las amas de casa peruanas en Internet? https://elcomercio.pe/economia/peru/comportan-amas-casa-peruanas-internet$\underline{179399}$

El Comercio. (2019, 24 febrero). Octógonos de advertencia ¿Qué son y por qué serán obligatorios desde el 17 de junio? Recuperado de https://elcomercio.pe/tecnologia/ciencias/octogonos-advertencia-sirven-seranobligatorios-junio-noticia-610351 
El Comercio. (2018, 4 abril). Amas de casa peruanas valoran cercanía de tiendas comerciales. Recuperado de

https://elcomercio.pe/economia/peru/50-amas-casa-peruanas-prioriza-cercania-

practicidad-noticia-509651

El Comercio. (2016, 7 marzo). Mujeres maravilla: el perfil de la consumidora peruana de hoy Recuperado de https://elcomercio.pe/economia/dia-1/mujeres-maravilla-perfilconsumidora-peruana-hoy-166181

Euromonitor. (25 de Enero de 2017). Las 10 principales tendencias globales de consumo para 2017. Obtenido de ResearchGate:

https://www.researchgate.net/publication/312880572_Las_10_principales_tende ncias_globales_de_consumo_para_2017

Euromonitor. (2019). Naturally Healthy Beverages in Peru. Recuperado de https://www.euromonitor.com/naturally-healthy-beverages-in-peru/report.

Gestión (2017, 28 marzo) Guerra musical: ¿Spotify representa amenaza para emisoras locales? Recuperado de

https://gestion.pe/tendencias/guerra-musical-spotify-representa-amenaza-emisoraslocales-131747

Gestion. (2019, 15 febrero). ¿Cuántas horas escuchan radio los peruanos? Recuperado de https://gestion.pe/tendencias/horas-escuchan-radio-peruanos-258759

Gestion. (2018, 16 abril). ¿Cuántas horas escuchan radio los peruanos? Recuperado de https://gestion.pe/tendencias/horas-escuchan-radio-peruanos-231412

Ipsos Apoyo. (2017). Medios Tradicionales: Hábitos y Actitudes . Lima : Ipsos.

Ipsos Apoyo. (2018). Internet: Hábitos, usos y actitudes hacia Internet . Lima : Ipsos.

Ipsos Apoyo. (2017). Productos comestibles: Liderazgo en productos comestibles. Lima : Ipsos.

Ipsos Apoyo. (2018). Amas de casa: Perfil del Ama de Casa. Lima : Ipsos.

Ipsos. (2012). IGM - Hábitos y Actitudes hacia la prensa escrita 2012. Recuperado de https://www.ipsos.com/sites/default/files/2017-02/MKTData_Prensa_escrita_2012.pdf

Ipsos. (2015).La tele en los tiempos del internet. Recuperado de https://www.ipsos.com/es-pe/la-tele-en-los-tiempos-del-internet

Ipsos. (2016, 24 febrero) Hábitos y actitudes hacia la radio 2015. Recuperado de https://www.ipsos.com/es-pe/habitos-y-actitudes-hacia-la-radio-2015

Katherinepastel (2 febrero mayo, 2015) Re: FRUTÍSIMOS DE NEGRITA: LO MÁS PARECIDO A LO NATURAL Y CON STEVIA [Post en un blog]. Recuperado de 
https://katherinepastel.wordpress.com/2015/02/02/frutisimos-de-negrita-lo-masparecido-al-natural-y-con-stevia/

La República (2018, 21 febrero). Datum presenta estudio sobre "vida saludable". Recuperado de https://larepublica.pe/marketing/1200803-datum-presenta-estudio-sobrevida-saludable

NETJOVEN (2019, 5 marzo). Recuperado de https://netjoven.pe/actualidad/128960/Marca-Peru-Historia-de-la-deliciosa-chichamorada.html

Revista ANDA. (2017). La nueva ama de casa: mujer recargada y superpoderosa. Recuperado de https://www.ipsos.com/sites/default/files/ct/publication/documents/2017-10/La-nuevaama-de-casa-mujer-recargada-y-superpoderosa.PDF

Revista ANDA. (2018, agosto). El ama de casa desea dejar el nido y volar muy alto. Recuperado de https://www.ipsos.com/sites/default/files/ct/publication/documents/201809/el_ama_de_casa_desea_dejar_el_nido_y_volar_muy_alto.pdf

Redacc. (16 marzo, 2017) Re: ¿Qué es el Posicionamiento Web o SEO? [Post en un blog] Recuperado de https://www.genwords.com/blog/seo 


\section{ANEXOS}

\section{Benchmark}

Naturale INICIO NOSOTROS PRODUCTOS

EMPRESAS

DOCUMENTOS CONTACTO $f$ 㟧

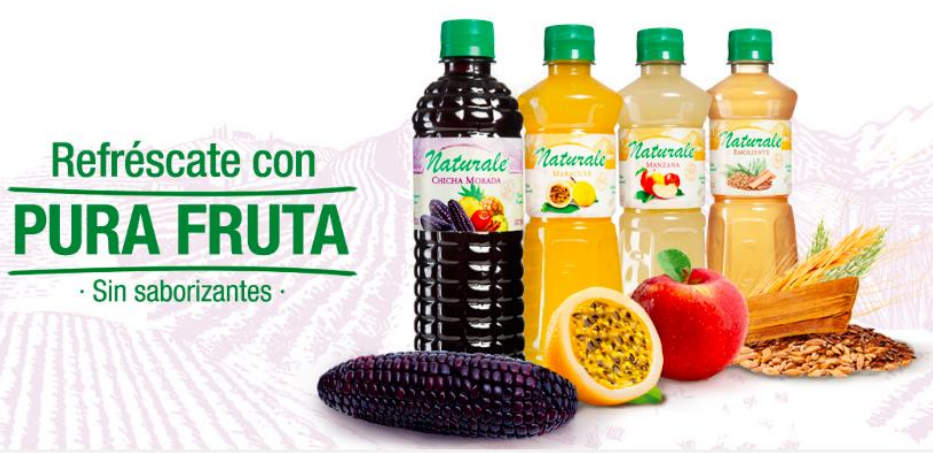

\section{CHICHA MORADA}
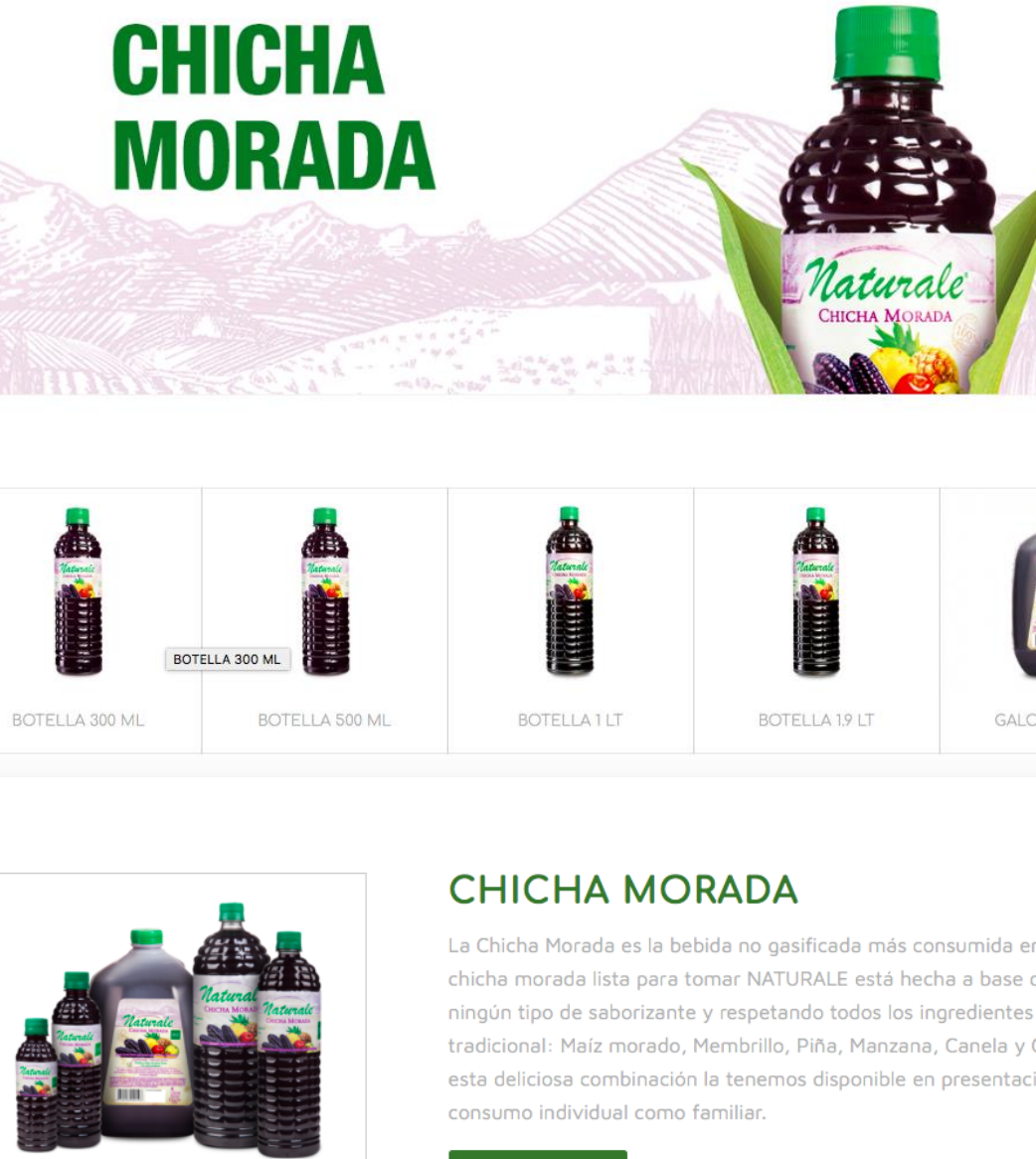

CHICHA MORADA

La Chicha Morada es la bebida no gasificada más consumida en el Pais. Nuestra chicha morada lista para tomar NATURALE está hecha a base de pura fruta, si ningún tipo de saborizante y respetando todos los ingredientes de la receta tradicional: Maiz morado, Membrillo, Piña, Manzana, Canela y Clavo de olor. Toda esta deliciosa combinación la tenemos disponible en presentaciones ideales para 


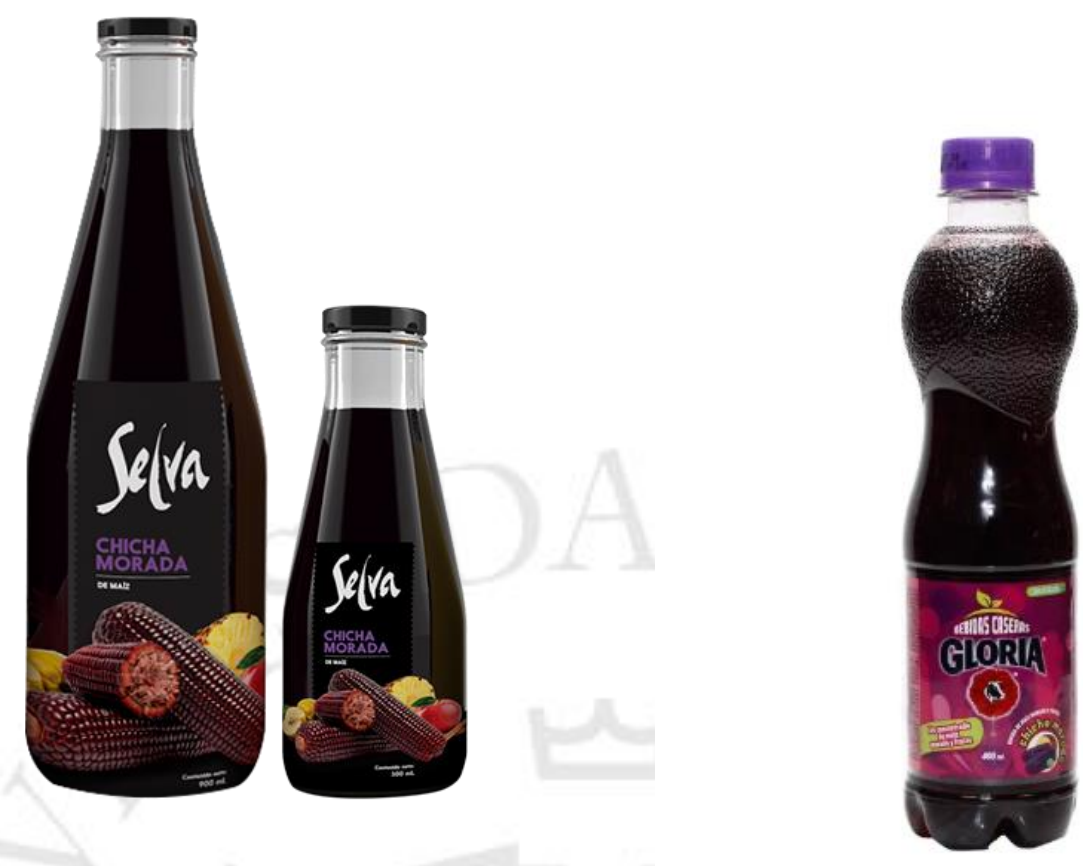

2. Guión técnico spot TV

https://docs.google.com/spreadsheets/d/1WpC9GAqegCk7nNMK4cU04LYfj9v0Yn_63 cSF0n6uFjM/edit?usp=sharing 


\begin{tabular}{|c|c|c|c|c|c|}
\hline \multicolumn{6}{|c|}{ GUIÓN TÉCNICO - SPOT CHICHA ANDINA } \\
\hline Escena & Plano & Imagen & Sonido & Storyboard & Tiempo \\
\hline \multirow{2}{*}{1} & Giran plano general & Panorma de los Andes & \multirow{2}{*}{$\begin{array}{l}\text { Loc. Off } \\
\text { Música andina. } \\
\text { Desde los Andes te } \\
\text { presentamos Chicha } \\
\text { Andina, la esencia } \\
\text { natural del Perú }\end{array}$} & & $\begin{array}{c}1 \\
\text { segundo }\end{array}$ \\
\hline & Plano general & $\begin{array}{l}\text { Cosecha de maíz morado, } \\
\text { membrillo, limón y pin̂́a }\end{array}$ & & & $\stackrel{5}{\text { segundos }}$ \\
\hline \multirow{3}{*}{2} & Plano entero & $\begin{array}{l}\text { La botella gira para mostrar } \\
\text { su disen̂́o andino }\end{array}$ & \multirow{3}{*}{$\begin{array}{l}\text { Loc. Off: } \\
\text { Bebida refrescante } \\
100 \% \text { saludable, sin } \\
\text { azúcar y lista para } \\
\text { preparar }\end{array}$} & & $\begin{array}{l}3 \\
\text { segundos }\end{array}$ \\
\hline & Primer plano & $\begin{array}{l}\text { Líquido de la botella } \\
\text { sirviéndose en una jarra con } \\
\text { agua }\end{array}$ & & & $\begin{array}{l}3 \\
\text { segundos }\end{array}$ \\
\hline & Plano cerrado & $\begin{array}{l}\text { Imagen del líquido } \\
\text { moviéndose con el agua }\end{array}$ & & & $\begin{array}{c}1 \\
\text { segundos }\end{array}$ \\
\hline 3 & Plano medio & $\begin{array}{l}\text { El niño toma la chicha y se le } \\
\text { forma un bigote de chicha, } \\
\text { pasa su lengua por el bozo } \\
\text { para limpiarlo. Y el nir̂́o está } \\
\text { dice con el dedo que está } \\
\text { muy rico. }\end{array}$ & $\begin{array}{l}\text { Loc. Dff: } \\
\text { Con efecto } \\
\text { antioxidante, } \\
\text { mantendrás sana a } \\
\text { toda tu familia }\end{array}$ & & $\stackrel{5}{\text { segundos }}$ \\
\hline 4 & Plano medio & $\begin{array}{l}\text { Collage de varias familias } \\
\text { consumiendo el producto, } \\
\text { mamas con hijos, papas y } \\
\text { mamas con hijos. }\end{array}$ & $\begin{array}{l}\text { Chicha Andina la } \\
\text { I fusión de ingrediente } \\
\text { más rica del Perú. } \\
\text { Encuéntranos en tu } \\
\text { supermercadoy } \\
\text { t tiendas orgánicas } \\
\text { favoritas. }\end{array}$ & & $\begin{array}{l}8 \\
\text { segundos }\end{array}$ \\
\hline
\end{tabular}

\section{Encuesta}

Para escoger el nombre de nuestro concentrado de chicha morada, realizamos una encuesta a 120 mujeres amas de acá de niveles socioeconómico A, B y C. Las cuales les preguntamos por 8 nombres diferentes para que ellas nos digan cuál les gustaría más para este nuevo producto que se lanzará al mercado.

\section{¿A qué asocia la chicha morada?}

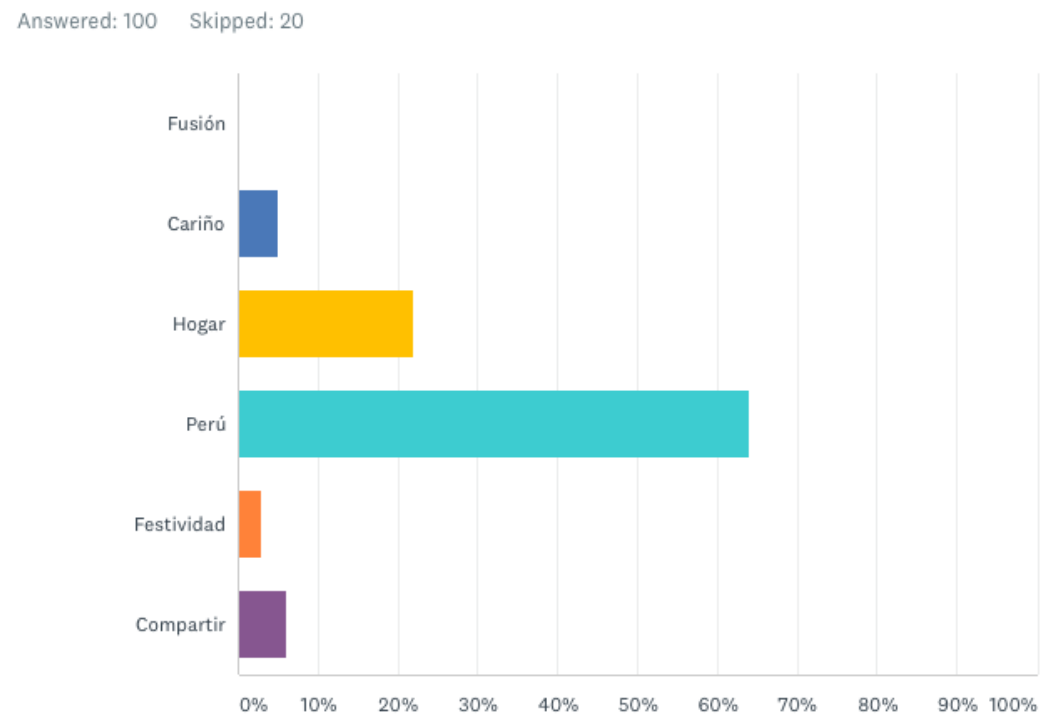




\begin{tabular}{llc} 
OPCIONES DE RESPUESTA & RESPUESTAS & - \\
\hline Taki & $5,00 \%$ & 5 \\
\hline Incarú & $4,00 \%$ & 4 \\
\hline Chicha Andina & $47,00 \%$ & 47 \\
\hline Sanicha & $6,00 \%$ & 6 \\
\hline Incarucha & $1,00 \%$ & 1 \\
\hline Mama Chicha & $4,00 \%$ & 4 \\
\hline Asua & $29,00 \%$ & 29 \\
\hline TOTAL & $4,00 \%$ & 4 \\
\hline
\end{tabular}

El nombre que más les gusto y por el que votaron fue Chicha Andina con un $47 \%$ de votación, en segundo lugar, quedó Mamá Chicha con un 29\%. Los otros nombres propuestos como Sanicha, Taki, Incarú, Inca Andina y Asua tuvieron muy poca votación y no cumplieron las expectativas con nuestro público objetivo.

Por otro lado, preguntamos a las amas de casa con qué relacionan asocian la chicha morada.

\begin{tabular}{lcc} 
OPCIONES DE RESPUESTA & RESPUESTAS & 0 \\
\hline Fusión & $0,00 \%$ & 5 \\
\hline Cariño & $5,00 \%$ & 22 \\
\hline Hogar & $22,00 \%$ & 64 \\
\hline Perú & $64,00 \%$ & 3 \\
\hline Total & $3,00 \%$ & 6 \\
\hline
\end{tabular}

La mayoría respondió que lo asocian al Perú con un 64\%, quedando en segundo lugar al Perú. Al hogar lo relaciona un $22 \%$ de nuestras amas de casa encuestadas. Un $6 \%$ asocian la chicha morada con al compartir, $5 \%$ de ellas al cariño, $3 \%$ a la festividad. Sin embargo, ninguna de nuestro público objetivo asocia a la chicha morada con Fusión. Por último, realizamos una pregunta abierta para que las amas de casa nos respondan lo primero que le viene a la menta respecto a la chicha morada:

\section{¿Qué es lo primero que se le viene a la mente cuando le digo chicha morada?}

Por lo que las respuestas que más se repitieron fueron las siguientes:

Perú, refresco, mamá, bebida refrescante, antioxidante, casa, maíz morado. 
PERU

23/04/2019 21:26

Ver las respuestas del encuestado

Agregar etiquetas

\section{Refresco natural}

23/04/2019 21:26

Ver las respuestas del encuestado

Agregar etiquetas

Maíz

23/04/2019 21:26

Ver las respuestas del encuestado

Agregar etiquetas $\nabla$

\section{Mamá}

23/04/2019 21:25

Ver las respuestas del encuestado

Agregar etiquetas $\nabla$

\section{Maíz morado y limon}

23/04/2019 21:59

Ver las respuestas del encuestado

Agregar etiquetas $\nabla$

bebida peruana

23/04/2019 21:59

Ver las respuestas del encuestado

Agregar etiquetas $\nabla$

Una bebida rica y refrescante, que podría tomarla todo el día

$23 / 04 / 201921: 50$

Ver las respuestas del encuestado

Agregar etiquetas $\vee$

Salud

$23 / 04 / 201921: 43$

Ver las respuestas del encuestado

Agregar etiquetas 
Perú

23/04/2019 22:14

Es un antioxidante

23/04/2019 22:14

Casa

23/04/2019 22:13

Maiz

23/04/2019 22:12

Ver las respuestas del encuestado

Agregar etiquetas $\nabla$

\section{Empaque Chicha Andina}

\subsection{PACKAGING BOTELLA - ILUSTRACIONES}

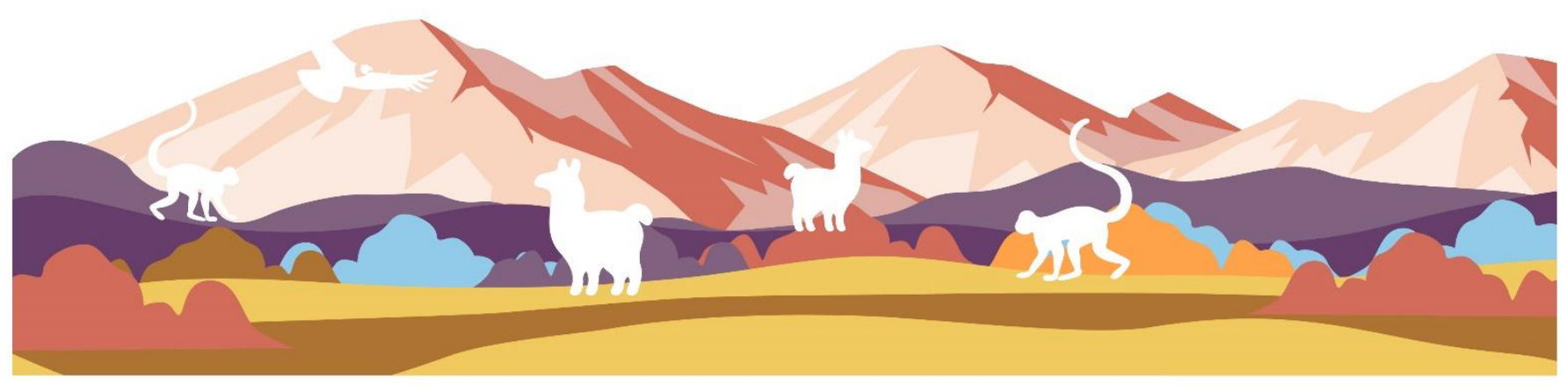




\begin{tabular}{|c|c|c|c|c|}
\hline $\begin{array}{l}\text { TOTAL DE } \\
\text { ANUNCIOS }\end{array}$ & $\begin{array}{l}\text { INVERSION POR } \\
\text { ANUNCIO SOLES }\end{array}$ & $\begin{array}{l}\text { INVERSION POR } \\
\text { ANUNCIO DOLARES }\end{array}$ & $\begin{array}{l}\text { TIPO DE } \\
\text { CAMBIO }\end{array}$ & $\begin{array}{l}\text { TOTAL } \\
\text { DOLARES }\end{array}$ \\
\hline & $\mathrm{S} / .108,900.00$ & $\$ 33,000$ & 3.3 & $\$ 32,400$ \\
\hline & S/.42,101.40 & $\$ 12,758$ & 3.3 & $\$ 12,758$ \\
\hline & S/.14,850.00 & $\$ 4,500$ & 3.3 & $\$ 4,500$ \\
\hline & $\mathrm{S} / .13,200.00$ & $\$ 4,000$ & 3.3 & $\$ 4,000$ \\
\hline & $S / 29,700.00$ & $\$ 9,000$ & 3.3 & $\$ 9,000$ \\
\hline & S/.4,498 & $\$ 1,363$ & 3.3 & $\$ 1,363$ \\
\hline
\end{tabular}




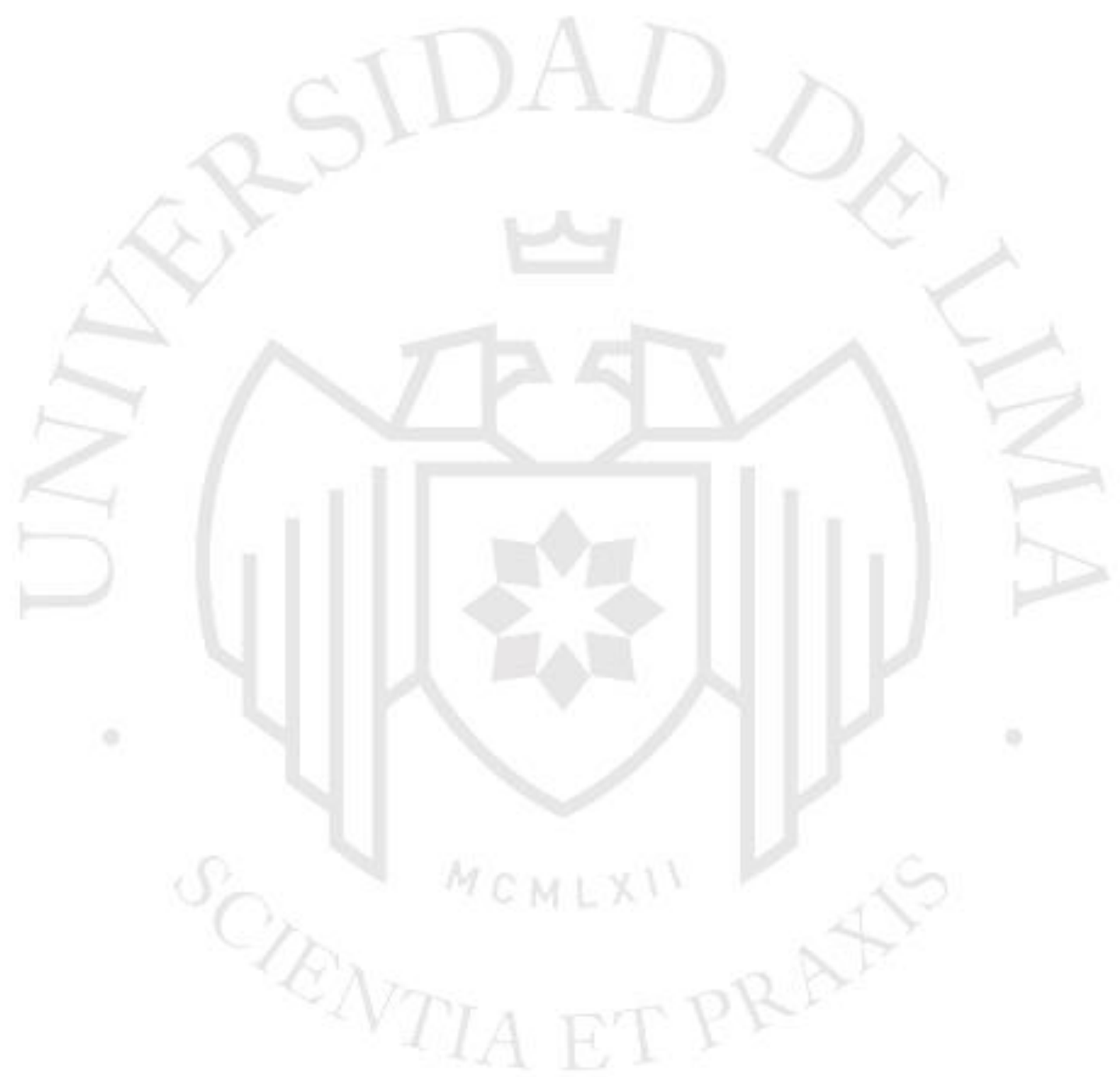




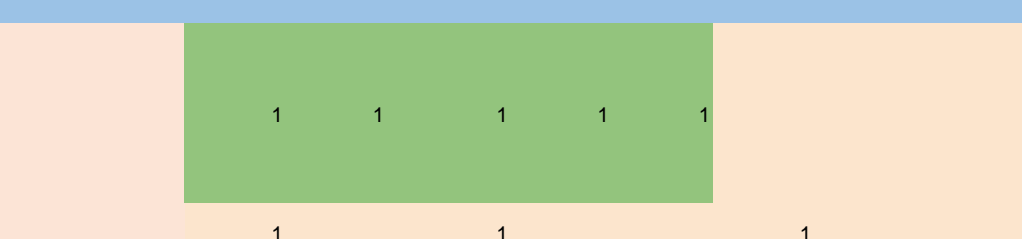

(n)

video Paloma Derteano +

TV - El artista de año

TV - America TV De Vuelta al Barrio

TV. América TV Mi mamá cocina

mejor que la tuya

Movistar Plus - Ximena En Casa

Planeta 107.7

R.P.P.

Oxigeno

Prensa El Comercio

Revista SOMOS

Facebook

BTL - degustación tiendas orgánicas $x$

Semana 1
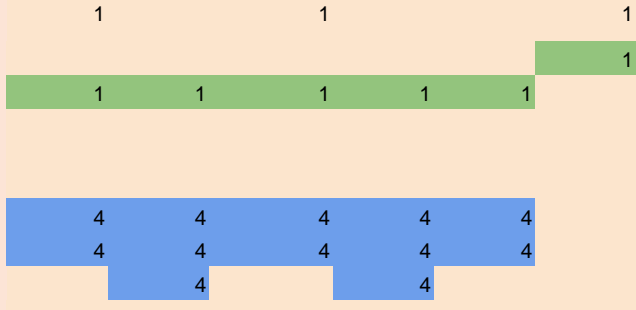

BTL - músicos con instrumentos

andinos $y$ degustacion $x 10$

Influencer video Karen Schwarz +

pauta

TV - El artista de año

TV - America TV De Vuelta al Barrio

TV . América TV Mi mamá cocina

mejor que la tuya

Movistar Plus - Xmena En Casa Semana 2

R.P.P.

Oxigeno

Revista SOMOS

Instagram

Facebook

Influencer video Ximena Llosa + sorteo

pasaje Cusco

TV - El artista de año

TV - America TV De Vuelta al Barrio

TV . América TV Mi mamá cocina

mejor que la tuya

Movistar Plus - Xmena En Casa

Planeta 107.7

Oxigeno

Revista SOMOS

Instagram

Facebook

Semana 3

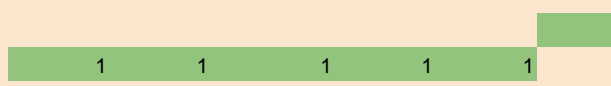

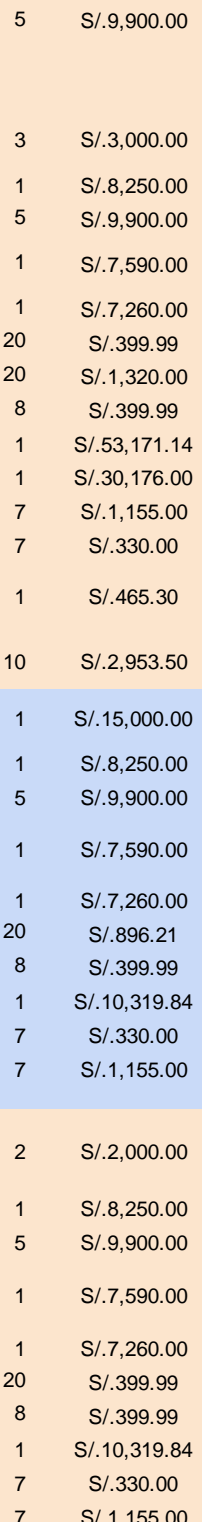

$\$ 3,000.00$

$\$ 15,000$

$\$ 909.09$

$\$ 2,500.00$

$\$ 3,000.00$

$\$ 2,300.00$

$\$ 2,200.00$

$\$ 121.21$

$\$ 400.00$

$\$ 121.21$

$\$ 16,112.4$

$\$ 7,639.24$

$\$ 350.00$

$\$ 100.00$

$\$ 141.00$

$\$ 895.00$

$\$ 4,545.45$

$\$ 2,500.00$

$\$ 3,000.00$

$\$ 2,300.00$

$\$ 2,200.00$

$\$ 271.58$

$\$ 121.21$

$\$ 3,127.22$

$\$ 100.00$

$\$ 350.00$

$\$ 606.06$

$\$ 2,500.00$

$\$ 3,000.00$

$\$ 2,300.00$

$\$ 2,200.00$

$\$ 121.21$

$\$ 121.21$

$\$ 3,127.22$

$\$ 100.00$

$\$ 350.00$ 


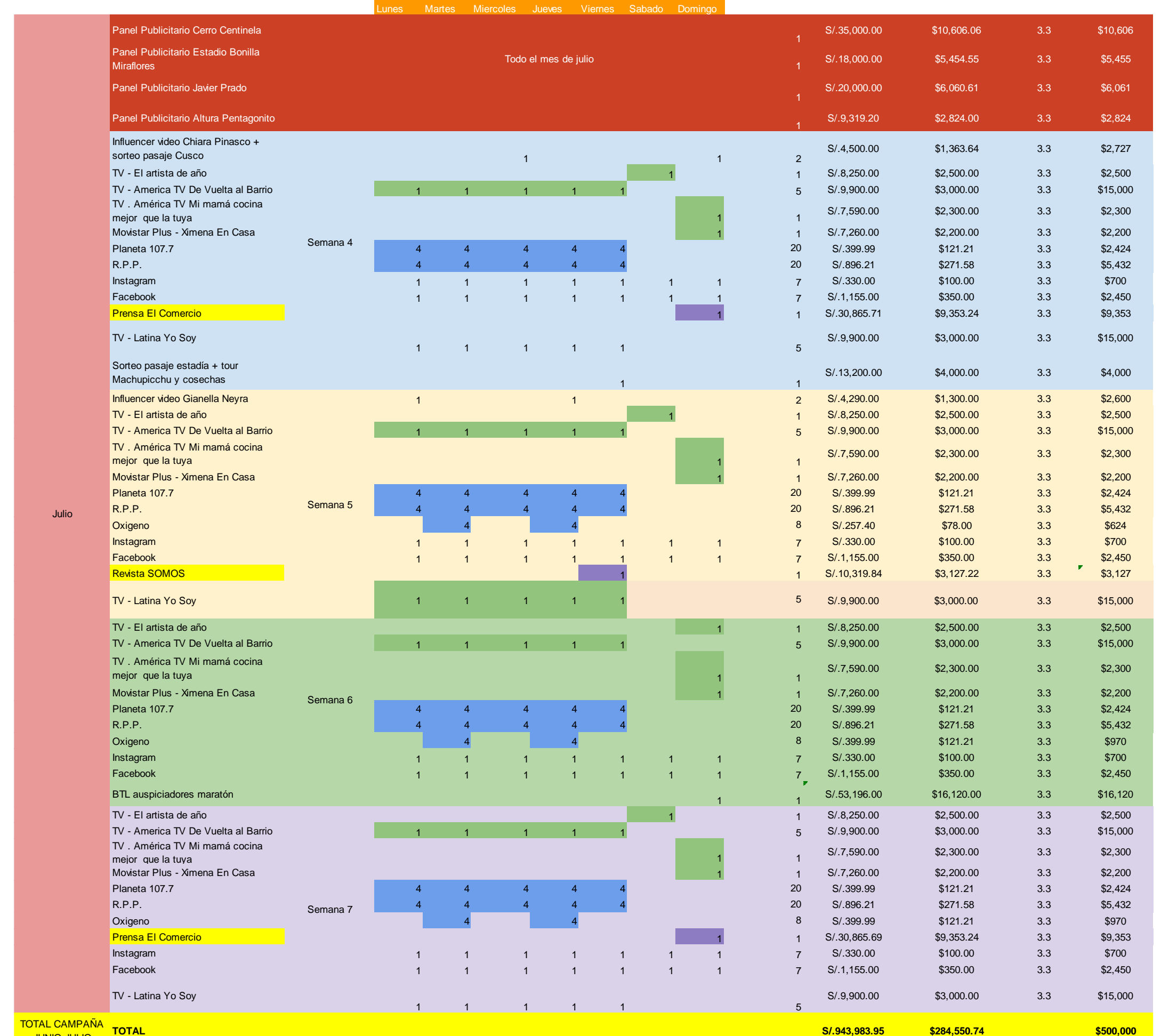

